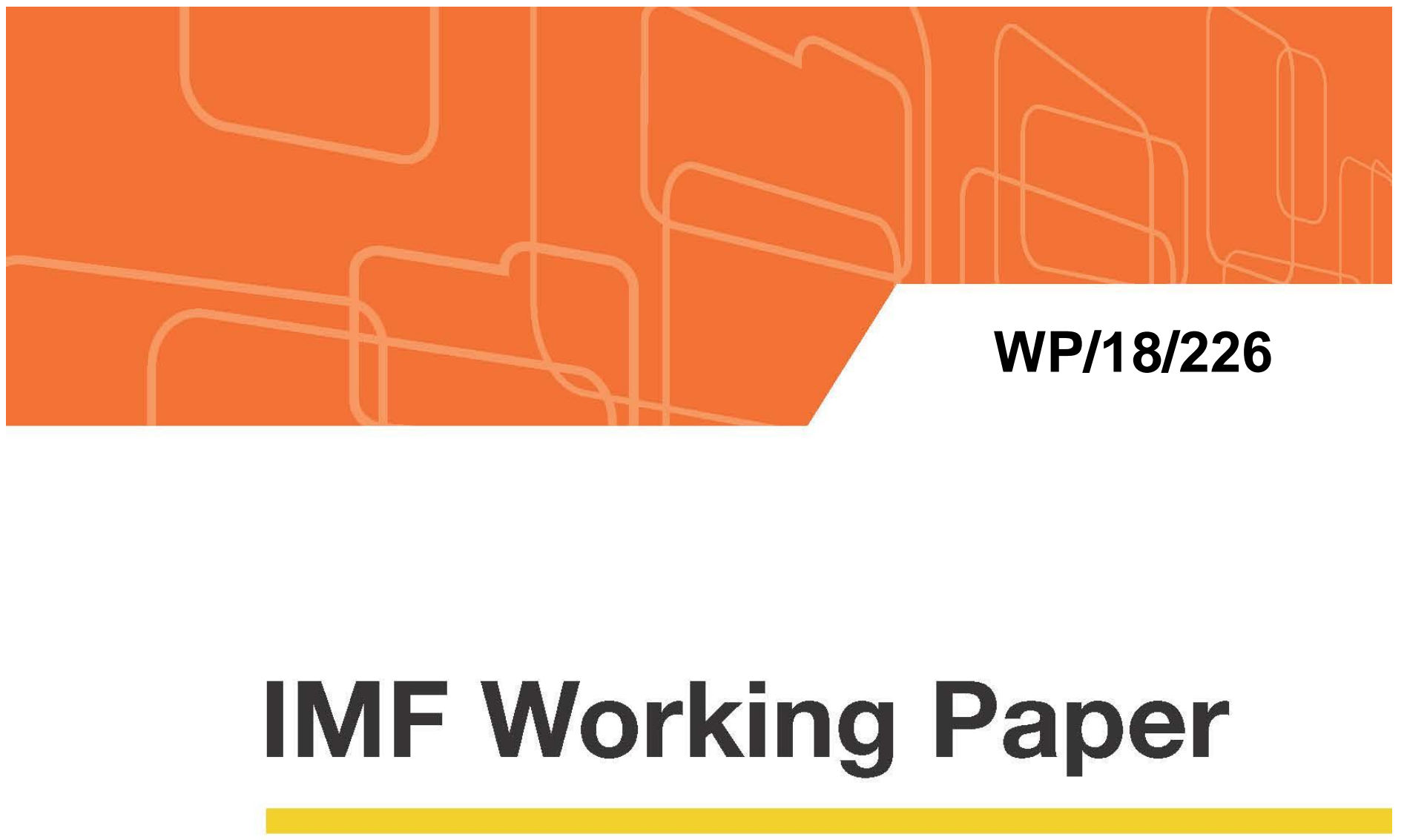

\title{
Business Cycle with Bank Intermediation in Oil Economies
}

by Hamid Reza Tabarraei, Hamed Ghiaie, and Asghar Shahmoradi

IMF Working Papers describe research in progress by the author(s) and are published to elicit comments and to encourage debate. The views expressed in IMF Working Papers are those of the author(s) and do not necessarily represent the views of the IMF, its Executive Board, or IMF management.

$$
\text { I N T E R N A T | O N A L M O N E T A R Y F U N D }
$$




\title{
IMF Working Paper
}

Middle East and Central Asia Department

\section{Business Cycle with Bank Intermediation in Oil Economies ${ }^{i}$ \\ Prepared by Hamid Reza Tabarraei, Hamed Ghiaie, and Asghar Shahmoradi}

Authorized for distribution by Hossein Samiei

October 2018

IMF Working Papers describe research in progress by the author(s) and are published to elicit comments and to encourage debate. The views expressed in IMF Working Papers are those of the author(s) and do not necessarily represent the views of the IMF, its Executive Board, or IMF management.

\begin{abstract}
The structural model in this paper proposes a micro-founded framework that incorporates an active banking sector with an oil-producing sector. The primary goal of adding a banking sector is to examine the role of an interbank market on shocks, introduce a national development fund and study its link to the banking sector and the government. The government and the national development fund directly play key roles in the propagation of the oil shock. In contrast, the banking sector and the labor market, through perfect substitution between the oil and non-oil sectors, have major indirect impacts in spreading shocks.

JEL Classification Numbers: E44, E50, E58, G01, G21, G33

Keywords: Oil-exporting countries, Banking, Oil-Reserve Fund, DSGE

Author's E-Mail Address: htabarraei@imf.org, hamed.ghiaie@u-cergy.fr, ashahmoradi@imf.org
\end{abstract}

\footnotetext{
i The authors thank Timothy Callen, Hossein Samiei, Selim Cakir, Gabriel Desgranges, Cyrus Sassanpour, and Mouhamadou Sy for their valuable comments. The views expressed herein are those of the authors and should not be attributed to the IMF, its Executive Board, or its Management.
} 


\section{Contents}

1 Introduction $\quad 2$

2 Model $\quad 5$

2.1 Households . . . . . . . . . . . . . . . . . . . . 6

2.2 The Final Good Producer . . . . . . . . . . . . . . . . . . . . 7

2.3 Intermediate Goods Producers . . . . . . . . . . . . . . . . . . . 8

2.4 Capital Producers . . . . . . . . . . . . . . . . . . 10

2.5 Oil Sector . . . . . . . . . . . . . . . . . . . . . 11

2.6 Financial sector . . . . . . . . . . . . . . . . . 12

2.6.1 Deposit Banks . . . . . . . . . . . . . . . . 12

2.6.2 Lending Banks . . . . . . . . . . . . . . . . 13

2.7 Government . . . . . . . . . . . . . . . . . . 15

2.8 Central Bank and national development fund . . . . . . . . . . . . . . 16

2.9 Market clearing . . . . . . . . . . . . . . . . . 16

3 Results $\quad 17$

3.1 Technology Shocks . . . . . . . . . . . . . . . . . 17

3.2 Oil Price Shock . . . . . . . . . . . . . . . . . . . . . . . . 19

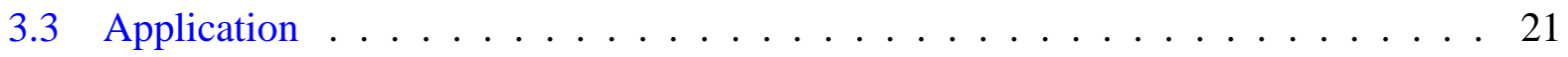

4 Concluding remarks $\quad 23$

$\begin{array}{ll}\text { References } & 25\end{array}$ 


\section{Introduction}

The recent oil price fluctuation has created concerns for the majority of oil-exporting countries and particularly for OPEC members. For Gulf countries, hydrocarbon exports represent more than half of total exports (Figure 1). Oil revenues account for 80 percent of total fiscal revenues, on average, and about 20 percent of GDP (Figure 2). In addition, the projection prices for oil fall below fiscal breakeven prices, in the medium-term for most countries (Figure 3). In many of oil-exporting countries, the financial sector has grown fairly large, and macro-financial linkages can exacerbate oil price shocks (Figure 4). The high volatility of oil prices could build systemic financial sector vulnerabilities, which in turn could adversely affect the real economy.

This study examines the relationship between macroeconomic aggregates, the financial sector, and the channels through which the business cycle and the financial cycle in oil economies interact. Unlike the growing body of literature assessing the effectiveness of policies and their underpinning theoretical models after the global crisis, the nexus between financial and oil price shocks has not been as fully explored. Most research in business cycle abstracts either from the role of commodities altogether or underestimates the role of the financial sector in commodity-exporting economies in accelerating the propagation of commodity shocks. Consequently, practitioners are left with limited knowledge on the macro-financial linkages for these economies.

Oil price fluctuations have a major impact on the public finances of developing, oil-exporting countries. The budget structure, the inability to smooth spending due to a lack of pertinent financial instruments, and limited access to credit markets combined with political and institutional constraints force governments to conduct procyclical fiscal policies (see for example Murphy et al. (2010) and Erbil (2011)), when facing an oil shock. Moreover, in most oil-dependent countries government investment expenditure and current spending drive non-oil GDP growth (Figures 5 and 6). As a result, oil price fluctuation determines the business cycle in the absence of a welldiversified economy.

The structural model in this paper proposes a micro-founded framework that incorporates an active banking sector, including an interbank market, into a DSGE model with an oil-producing sector. Although there is an oil revenue windfall, the economy is modeled as an autarky and it 
abstracts from exchange rate regimes. In addition to other traditional sectors in the real economy, the model includes a national oil fund collecting a share of oil revenue and a fiscal regime that depends on this fund in addition to oil revenues. This setting allows us to analyze the role of fiscal policy in transmission of the oil price volatility to the economy, as discussed in Tazhibayeva et al. (2008), Arezki and Ismail (2013) and Pieschacón (2012). The fiscal policy is guided by the public policy objective to increase capital expenditure, household incomes by transfers, and subsidies to firms as a means of sharing the oil revenue as suggested in Chemingui and Roe (2008). The result is a highly procyclical fiscal regime in line with previous studies (Tazhibayeva et al. (2008), Murphy et al. (2010)). The national development fund acts as a saving fund but also as a stabilization fund to hedge against the liquidity risk in the banking system. To capture government involvement in state-owned enterprises (SOEs), we assumed that the government provides productive capital to intermediate goods producers.

Although the government fiscal regime remains a major player in the transmission of shocks, banks in this model are key agents in spreading shocks across sectors of the economy. Banks give commercial loans to firms that produce goods, purchase government bonds, and finance their operation partly by borrowing through the interbank market from deposit collector banks and partly by the national development fund, which acts as a stabilizer. The endogenous interbank rate depends on the supply of deposits, which in turn is reliant upon government transfer to households. Also, banks are key in determining government bond rates and interest rates on loans to good-producing firms, thereby linking the real business cycle to the financial cycle.

Oil price shocks can affect the financial sector through multiple channels. First, with lower revenues, the government must adjust its capital expenditure. The government usually holds a large stake in SOEs and entities in a variety of sectors, and many of these SOEs remain dependent on the government's financial support through subsidies and transfers. Therefore, lower oil revenues and government spending reflects in the economic activities of SOEs, which in turn contract out big projects to private sector companies. As government investment falls, many of these subcontracts to private firms will halt, and many investment projects will fail. Therefore, banks' nonperforming loans (NPLs) can increase not only as a result of direct exposure to SOEs but also because 
of the private sector's failing projects. Higher NPLs diminish the credit availability in an economy, particularly to the private sector where access to finance is often a challenge in oil-exporting countries.

Second, governments remain the main employer in developing, oil-exporting countries. As oil revenues drop, efforts to contain the public wage bill increase, resulting in declines in household disposable income, consumption, and, importantly, bank deposits. Higher households' financial fragility and the possibility of falling into arrears raises nonperforming loans, making credit less available to borrowers who are dependent on bank financing. This development also affects banks' ability to make new loans. Moreover, deposit volatility makes liquidity management difficult and costlier for banks, requiring them to borrow from the central bank (in absence of a developed interbank market) at a premium rate (see Choudhary and Limodio (2017)). Accordingly, because of the liquidity risk, the cost of supplying longer-term lending heightens.

Third, with a lower non-oil GDP growth rate due to an oil shock, the stock markets and housing market would stagnate. Because banks are highly exposed to these markets, higher credit risks emerge, which eventually feeds back into the real economy and leads to a lower credit to economy (Arouri et al. (2010), Fayyad and Daly (2011)). Other channels, such as lower international reserves accumulation and capital outflow, remain important in the long run.

For the sake of simplicity, not all of the aforementioned channels are modelled as just described. Nevertheless, several results prevail. First, the government role's in the propagation of shocks remains crucial. A positive oil shock boosts fiscal revenues and enlarges the fiscal space, which lets the government expand the social transfer to households and increase public capital expenditure. Wealthier households consume more, but their behavior on labor allocation also changes. Additionally, higher public investment raises non-oil output, which should result in a higher fiscal multiplier.

Second, due to complementarities between the oil and non-oil sectors in the model, the labor market becomes an important driver of shocks' diffusion. Because of fixed labor supply in the economy, this channel becomes important essentially for the oil-sector technology shock and the oil price shock. However, this hypothesis dampens the shock impacts on consumption and GDP 
and prevents the wage and prices from acting as automatic stabilizers to avoid large swings of production factors between sectors.

Finally, while banks do not have important roles in spreading the shocks, they have a critical role in amplifying them. This is because the oil sector is not directly exposed to the banking sector, the non-oil companies are not credit constrained, and the model abstracts from any credit default. However, the heterogenous banking system, including deposit and lending banks, differentiate various market interest rates between households, government, non-oil firms, the national development fund, and the central bank.

The rest of the paper is organized as follows. Section 2 spells out a stylized but large-scale small open economy DSGE model of an oil-exporter with eight type of agents including explicit macrofinancial links and demonstrate some of the channels that were discussed above. In section 3 , discusses the calibration of structural and policy parameters of the model based on Iran's economy and the impact of an oil price shock on macroeconomic aggregates and financial sector variables. Also, we study the impact of monetary shock under an inflation- targeting regime. Finally, we offer some concluding remarks.

\section{Model}

In this section, we develop a DSGE model for a perfectly competitive small open economy consisting of a real private sector, a financial sector, a central bank, and a government. The real sector includes households, non-financial good producers, capital producers, intermediate good producers, and an oil sector. Additionally, a portion of oil export proceeds is saved in a national development fund, which intervenes in the financial market by providing funds to the lending bank. The representative household consumes the final good sold by retailers and supplies labor to intermediate good producers. The household also deposits her savings in the deposit bank and is the ultimate beneficiary of both financial and non-financial firms. Intermediate goods producers are monopolistically competitive and use private and public capital to produce goods. Retailers buy goods from final goods producers and mark up prices via monopolistic competition with nomi- 
nal price rigidities à la Christiano et al. (2005), Fernández-Villaverde and Rubio-Ramírez (2009) and Smets and Wouters (2007).The oil sector uses capital and labor to extract oil to sell abroad at international prices.

The financial sector consists of a deposit bank and a lending bank forming an interbank market. The deposit banks offer a one-period financial instrument to households, namely de- posits, and lend to the lending banks at the interbank rate. The deposit contract is subject to a quadratic adjustment cost of deposit rates à la Gerali et al. (2010a) due to monopolistic power of deposit banks. Lending banks provide one-period loan contracts to goods producers and the government. In addition to the interbank market funding, lending banks use resources from the national development fund at the central bank policy rate. The government issues one-period bonds, collects taxes, and uses a fraction of oil revenues and the national development fund resources. The national development fund also receives a share of oil revenues and finances parts of government expenditure and the banking sector's needs. The central bank is independent from the government and follows an inflation targeting policy by using the Taylor rule.

\subsection{Households}

Households maximize their life-time utility function driven from consumption and leisure time. The representative household's intertemporal preference is

$$
\max _{C_{t}, N_{t}, D_{t}} \mathbb{E}_{t}\left\{\sum_{s=t}^{\infty} \beta^{s-t} U\left(C_{s}, N_{s}\right)\right\}
$$

with $0<\beta<1$. $C_{t}$ and $N_{t}$ denote consumption and the number of hours worked. We assume the single period utility function as:

$$
U\left(C_{t}, N_{t}\right)=\frac{C_{t}^{1-\sigma}}{1-\sigma}-\chi_{N} \frac{N_{t}^{1+\phi}}{1+\phi}
$$

with $\chi_{N}, \phi>0 . \sigma$ denotes households risk aversion and $\phi$ represents the inverse of the Frisch elasticity of labor supply. The disutility for work is weighted by $\chi_{N}$. In each period, the household 
consumes $C$, despoit $D$ in banks and pay taxes $T$. Households supply labor $N$ to the intermediate goods and oil producers, receive wages $W$ and the previous period deposits return $R^{D}$, transfer $\Gamma$ from the government, and net payouts $\mathbb{P}$, from the ownership of both financial and non-financial firms. Therefore, households budget constraint is

$$
C_{t}+D_{t+1}+T_{t} \leq W_{t} N_{t}+\frac{R_{t}^{D} D_{t}}{\Pi_{t+1}}+\Gamma_{t}+\mathbb{P}
$$

The first order conditions in respect to consumption, deposit and labor are,

$$
\begin{aligned}
\lambda_{t} P_{t}^{H} & =C_{t}^{-\sigma} \\
\frac{N_{t}^{\phi}}{C_{t}^{-\sigma}} & =\frac{W_{t}}{\chi_{N}} \\
\frac{1}{R_{t+1}^{D}} & =\beta \mathbb{E}_{t}\left(\frac{1}{\Pi_{t+1}} \frac{C_{t+1}}{C_{t}}\right)^{-\sigma}
\end{aligned}
$$

where $\lambda$ is the Lagrangian and $\Pi_{t}$ is inflation. Households hold government debt indirectly through the financial sector ${ }^{1}$.

\subsection{The Final Good Producer}

In a perfectly competitive market, a final good is produced by using intermediate goods. Taking as given all intermediate goods prices $P^{H}(i)$ and the final good price $P^{H}$, the final good producer's maximizes profit subject to its production function:

$$
\begin{gathered}
\max _{Y_{t}(i)} P_{t}^{H} Y_{t}^{H}-\int_{0}^{1} P_{t}^{H}(i) Y_{t}^{n}(i) d i \\
\text { s.t } \\
Y_{t}^{H}=\left(\int_{0}^{1} Y_{t}^{n}(i)^{\frac{\theta-1}{\theta}} d i\right)^{\frac{\theta}{\theta-1}}
\end{gathered}
$$

\footnotetext{
${ }^{1}$ Gertler and Karadi (2011) show that holding government debt directly or indirectly does not matter in such models.
} 
where $\theta$ is the elasticity of substitution. By solving the problem, the input demand functions are

$$
Y_{t}^{n}(i)=\left(\frac{P_{t}^{H}(i)}{P_{t}^{H}}\right)^{-\theta} Y_{t}^{H} \quad \forall i
$$

where $Y^{H}$ is the aggregate demand. The zero profit condition conducts

$$
P_{t}^{H}=\left(\int_{0}^{1} P_{t}^{H}(i)^{1-\theta} d i\right)^{\frac{1}{1-\theta}}
$$

\subsection{Intermediate Goods Producers}

A continuum of intermediate goods producers use the Cobb-Douglas production technology to produce intermediate goods that are sold to final producers. These firms face a two-stage problem. In the first stage, an intermediate good producer maximizes her profit subject to her supply curve, taking wage, $W$, and capital rent, $R^{k}$, as given,

$$
\begin{aligned}
\max _{K_{t}, N_{t}} & \Pi_{t}^{n}=P_{t}^{H} Y_{t}^{n}+\left(1-\delta_{k}\right) P_{t}^{k} K_{t}-(1-u) R_{t}^{k} P_{t-1}^{k} K_{t}-W_{t} N_{t}^{n} \\
\text { s.t } & \\
Y_{t}^{n} & =A_{t}\left(K_{t}\right)^{\gamma_{n}}\left(K_{t-1}^{G}\right)^{\gamma_{G}}\left(N_{t}^{n}\right)^{1-\gamma_{n}}
\end{aligned}
$$

where $K^{G}$ is the stock of public capital ${ }^{1}$ raised by the government at the end of $t-1$ with $\gamma_{n}, \gamma_{G}>$ 0 . Every period, the intermediary good producer raises loan $L$ in order to finance its required capital. The producer acquires capital $K_{t+1}$ from the capital producer at price $P_{t}^{k}$ in order to produce in the subsequent period,

$$
L_{t}=P_{t}^{k} K_{t+1}
$$

\footnotetext{
${ }^{1}$ Leeper et al. (2010) and Berg et al. (2013) use the same structure.
} 
The producer will sell the undepreciated part of capital to capital producers on the open market at the proper price. The firm chooses labor and capital in a perfectly competitive factor market:

$$
\begin{aligned}
R_{t}^{k} & =\frac{\gamma_{n} P_{t}^{H} Y_{t}^{n}+\left(1-\delta_{k}\right) P_{t}^{k} K_{t}}{L_{t-1}} \\
W_{t} & =\frac{\left(1-\gamma_{n}\right) P_{t}^{H} Y_{t}^{n}}{N_{t}^{n}}
\end{aligned}
$$

To find the real marginal cost, $m c$, we set the level of labor and capital to produce one unit of good, $A_{t}\left(K_{t}\right)^{\gamma_{n}}\left(K_{t-1}^{G}\right)^{\gamma_{G}}\left(N_{t}^{n}\right)^{1-\gamma_{n}}=1$. This equation, by using factor prices 12 and 13 , implies

$$
\begin{aligned}
& N_{t}^{n}=\frac{1}{A_{t}}\left(\frac{\gamma_{n}}{1-\gamma_{n}} \frac{W_{t}}{R_{t}}\right)^{-\gamma_{n}} \\
& m c_{t}=\left(\frac{1}{1-\gamma_{n}}\right)^{1-\gamma_{n}}\left(\frac{1}{\gamma_{n}}\right)^{\gamma_{n}} \frac{W_{t}^{1-\gamma_{n}} R_{t}^{\gamma_{n}}}{A_{t}\left(K_{t-1}^{G}\right)^{\gamma_{G}}}
\end{aligned}
$$

where $R_{t}=R_{t}^{k} P_{t-1}^{k}-\left(1-\delta_{k}\right) P_{t}^{k}$.

In the second stage, the intermediate good producer maximizes its discounted real profits. Following Fernández-Villaverde and Rubio-Ramírez (2009), a fraction $1-\alpha_{p}$ of producers might change their prices in each period to $P_{t}^{*}$. Other producers can only index their prices by past inflation. With the indexation parameter $\chi \in[0,1]^{1}$, the price index, using Calvo pricing model, evolves as follow:

$$
P_{t}^{H}=\left[\alpha_{p}\left(\Pi_{t-1}^{\chi} P_{t-1}^{H}\right)^{1-\theta}+\left(1-\alpha_{p}\right)\left(P_{t}^{*}\right)^{1-\theta}\right]^{\frac{1}{1-\theta}}
$$

The dynamic pricing problem of the firm is to maximize the sum of discounted real profit subject

\footnotetext{
${ }^{1}$ where $\chi=0$ is no indexation and $\chi=1$ is total indexation
} 
to its supply curve:

$$
\begin{gathered}
\max _{P_{t}^{H}} \mathbb{E}_{t} \sum_{\tau=0}^{\infty}\left(\beta \alpha_{p}\right)^{\tau} \frac{\lambda_{t+\tau}}{\lambda_{t}}\left[\left(\prod_{s=1}^{\tau} \Pi_{t+s-1}^{\chi} \frac{P_{t}^{H}(i)}{P_{t+\tau}^{H}}-m c_{t+\tau}\right) Y_{t+\tau}^{n}(i)\right] \\
\text { s.t } \\
Y_{t+\tau}^{n}(i)=\left(\prod_{s=1}^{\tau} \Pi_{t+s-1}^{\chi} \frac{P_{t}^{H}(i)}{P_{t+\tau}^{H}}\right)^{-\theta} Y_{t+\tau}^{H}
\end{gathered}
$$

where $\Pi_{t}=\frac{P_{t}^{H}}{P_{t-1}^{H}}$ is inflation. Since we have utility seperatable in consumption and the security market is complete, the stochastic discount factor (SDF) is similar across households. Also because firms are owned by households, the same SDF applies for the valuation of future profits of these firms. The solution $P_{t}^{*}$ after simplication implies

$$
\begin{aligned}
& X_{t}^{1}=\lambda_{t} m c_{t} Y_{t}^{H}+\beta \alpha_{p} E_{t}\left(\frac{\Pi_{t}^{\chi}}{\Pi_{t+1}}\right)^{-\theta} X_{t+1}^{1} \\
& X_{t}^{2}=\lambda_{t} \Pi_{t}^{*} Y_{t}^{H}+\beta \alpha_{p} E_{t}\left(\frac{\Pi_{t}^{\chi}}{\Pi_{t+1}}\right)^{1-\theta}\left(\frac{\Pi_{t}^{*}}{\Pi_{t+1}^{*}}\right) X_{t+1}^{2}
\end{aligned}
$$

where $\Pi_{t}^{*}=\frac{P_{t}^{*}}{P_{t}^{H}}$ and $\theta X_{t}^{1}=(\theta-1) X_{t}^{2}$.

\subsection{Capital Producers}

Competitive capital producing firms build new capital by using undepreciated part of capital from intermediate goods producers and new investment. The new capital is sold at price $P_{t}^{k}$ at time $t$. The capital accumulation dynamic is

$$
\begin{aligned}
K_{t} & =\left(1-\delta_{k}\right) K_{t-1}+\Phi\left(\frac{i_{t}}{i_{t-1}}\right) i_{t} \\
\Phi\left(\frac{i_{t}}{i_{t-1}}\right) & =1-\frac{\xi}{2} \frac{\left(\frac{i_{t}}{i_{t-1}}-1\right)^{2}}{\frac{i_{t}}{i_{t-1}}}
\end{aligned}
$$

where $\Phi($.$) is the non-linear investment adjustment cost function following Christiano et al. (2010).$ parameter $\xi$ measures the concavity of the technological constrains. The capital producer maxi- 
mizes it profit

$$
\max _{i_{s}} \quad \Pi_{t}^{K}=\mathbb{E}_{t} \sum_{s=t}^{\infty} M_{s, t}\left[P_{s}^{k} K_{s}-\left(1-\delta_{k}\right) P_{s}^{k} K_{s-1}-i_{s}\right]
$$

subject to the dynamic of capital accumulation, equation 20 where $M_{s, t}$ is the stochastic discount factor. $P_{t}^{k}$ is the Tobin's $\mathrm{Q}$ which determines the relative cost of investment in units of consumption. The price of depreciated capital and the new capital is assumed to be the same. The maximization problem implies

$$
P_{t}^{k}\left[\frac{i_{t}}{i_{t-1}} \Phi^{\prime}\left(\frac{i_{t}}{i_{t-1}}\right)+\Phi\left(\frac{i_{t}}{i_{t-1}}\right)\right]+\mathbb{E}_{t}\left[M_{t+1, t}\left(P_{t+1}^{k}\left(\frac{i_{t+1}}{i_{t}}\right)^{2} \Phi^{\prime}\left(\frac{i_{t+1}}{i_{t}}\right)\right)\right]=1
$$

The realized profit in each period is:

$$
\Pi_{t+1}^{K}=P_{t}^{k} K_{t}-\left(1-\delta_{k}\right) P_{t}^{k} K_{t-1}-i_{t}
$$

In the steady-state, the capital producer's profit is zero, whereas during the transition process around the steady-state, the adjustmnet cost cannot be set to its optimal level and the capital producers can realize a loss or profit because at time $t$, investment, $i_{t}$ is pre-determined.

\subsection{Oil Sector}

The government owns the oil sector, which follows a Cobb-Douglas production function, using capital and labor to extract oil. The oil production $Y^{o}$, is sold in the international open market at price $P^{o}$ without any friction. In each period, the government spends a fixed fraction $\alpha_{o}$ of the oil revenue as the new investment in the sector, partially to replace depreciated capital too.

$$
K_{t}^{o}=\left(1-\delta_{o}\right) K_{t-1}^{o}+\alpha_{o} P_{t}^{o} Y_{t}^{o}
$$


As a result, the oil sector maximizes its profit by choosing its required labor,

$$
\begin{gathered}
\max \quad \Theta_{t}=\left(1-\alpha_{o}\right) P_{t}^{o} Y_{t}^{o}-W_{t}^{o} N_{t}^{o} \\
\text { s.t } \\
Y_{t}^{o}=A_{t}^{o}\left(K_{t-1}^{o}\right)^{\gamma_{o}}\left(N_{t}^{o}\right)^{1-\gamma_{o}}
\end{gathered}
$$

the first order condition implies,

$$
N_{t}^{o}=\left(1-\alpha_{o}\right)\left(1-\gamma_{o}\right) \frac{P_{t}^{o} Y_{t}^{o}}{W_{t}}
$$

The oil sector is zero profit firm so it returns its profit to the government. We assume that the oil price follows an $A R(1)$ process,

$$
P_{t}^{o}=\rho_{o} P_{t-1}^{o}+\left(1-\rho_{o}\right) \bar{P}^{o}+\epsilon_{t}^{o}
$$

where $\epsilon_{t}^{o} \sim$ i.i.d $\left(0, \sigma_{o}^{2}\right)$

\subsection{Financial sector}

\subsubsection{Deposit Banks}

All net creditor financial intermediaries in the interbank market are referred to as deposit banks, which are price setters (that is monopolistically competitive). Each deposit bank $i \in(0,1)$ issues risk free deposit facilities for households and returns deposit interest $R_{t}^{D}(i)$ in the next period. These banks transfer the collected deposits to lending banks in the interbank market at the interbank rate $R_{t}^{I B}$. Given that banks are monopolistically competitive, a deposit bank $i$ faces a Dixit-Stiglitz loan demand curve ${ }^{1}$.

$$
D_{t}(i)=\left(\frac{R_{t}^{D}(i)}{R_{t}^{D}}\right)^{\varepsilon} D_{t}
$$

\footnotetext{
${ }^{1}$ As in Gerali et al. (2010b) and Dib (2010).
} 
where the demand is increasing in the relative deposit interest rate and $\varepsilon>1$ is the elasticity of substitution between different banks. $D_{t}(i)$ is deposit supplied to bank $i$ at the offered interest rate $R_{t}^{D}(i) . D_{t}$ and $R_{t}^{D}$ are the aggregate deposit and deposit rate taken as given by bank $i$. For setting the interest rates, deposit banks face a quadratic adjustment cost à la Rotemberg (1982) when maximizing its profit,

$$
\Pi_{t}^{D}=\max _{R_{t}^{D}(i)} \mathbb{E}_{t} \sum_{s=t}^{\infty} M_{s, t}\left\{\left(R_{t}^{I B}-R_{t}^{D}(i)\right) D_{t}(i)-\frac{\kappa_{D}}{2}\left(\frac{R_{t}^{D}(i)}{R_{t-1}^{D}(i)}-1\right)^{2} D_{t}\right\}
$$

The first order condition is simplified to

$$
\frac{1+\varepsilon}{\varepsilon} R_{t}^{D}=R_{t}^{I B}-\frac{\kappa_{D}}{\varepsilon}\left(\frac{R_{t}^{D}}{R_{t-1}^{D}}-1\right) \frac{R_{t}^{D}}{R_{t-1}^{D}}+\mathbf{E}_{t} \frac{M_{t+1, t}}{\varepsilon}\left(\frac{R_{t+1}^{D}}{R_{t}^{D}}-1\right) \frac{R_{t+1}^{D}}{R_{t}^{D}}
$$

where symmetric equilibrium implies $R_{t}^{D}(i)=R_{t}^{D}$ for all $i \in(0,1)$. Equation 31 shows that the interbank rate includes the risk-free deposit rate, deposit bank's markup and adjustment costs. This spread between free-risk rate and the inter-bank rate varies over the business cycle.

\subsubsection{Lending Banks}

In contrast, all net debtor financial intermediaries in the interbank market are referred to as lending banks. In addition to deposit resources, the lending bank has access to the central bank's loan $B_{t}^{C B}$ at rate $R_{t}^{C B}$. Each bank adds this bundle to its last-period profit, $\varpi$, in order to finance lending to firms, $L_{t}$, and buying government bonds, $B_{t}$. Raising any loan is subject to a quadratic adjustment cost. So, a lending bank's balance sheet (which is the same for all lending banks and therefore we look at the aggregate) can be written as:

$$
B_{t+1}+L_{t}=D_{t+1}+B_{t}^{C B}+\varpi_{t}
$$

where assets are government bonds, $B$, and loans, $L$, and liabilities are interbank borrowing which is equivalent to the aggregate deposit, $D$, borrowing from the central bank, $B^{C B}$ and the net worth, 
$\varpi$. The net worth dynamic changes according to:

$$
\begin{aligned}
\varpi_{t}=R_{t}^{k} L_{t-1}+R_{t}^{B} B_{t}-R_{t}^{I B} D_{t} & -R_{t-1}^{C B} B_{t-1}^{C B} \\
& -\frac{\eta_{D}}{2}\left(D_{t}-\bar{D}\right)^{2}-\frac{\eta_{B}}{2}\left(B_{t}-\bar{B}\right)^{2}-\frac{\eta_{L}}{2}\left(L_{t-1}-\bar{L}\right)^{2}
\end{aligned}
$$

where $\eta_{B}, \eta_{D}, \eta_{L}>0$. The quadratic terms are assumed, so that banks differentiate between rates in the economy. The banks maximize their intertemporal profits every period by

$$
\max _{L_{s}^{p}, L_{s}, B_{s}^{C B}, B_{s}} \Pi_{t}^{L}=\mathbb{E}_{t}\left[\sum_{s=t+1}^{\infty} M_{s, t} \varpi_{s}\right]
$$

subject to (32) and (33). The first order conditions imply:

$$
\begin{aligned}
R_{t}^{I B} & =\frac{R_{t-1}^{C B}}{1+\eta_{D}\left(D_{t}-\bar{D}\right)} \\
R_{t}^{B} & =\frac{R_{t-1}^{C B}}{1-\eta_{B}\left(B_{t}-\bar{B}\right)} \\
R_{t}^{k} & =\frac{R_{t-1}^{C B}}{1-\eta_{L}\left(L_{t-1}-\bar{L}\right)}
\end{aligned}
$$

To close the model, we assume that lending banks have unlimited access to national development fund resources at the policy rate $R_{t}^{C B}$ after exhausting other resources. Therefore, in addition to the deposit rate in (31), all other rates in the financial system are pinned down by the policy rate in equations (34) to (36). Each of these rates can be a markup or a markdown to the policy rate depending on the resources on asset and liability sides. For instance, if there is an excess liquidity in the banking system due to high levels of deposits, the interbank rate falls below the policy rate. Conversely, in a liquidity shortage, the interbank rate is higher than the central bank rate. 


\subsection{Government}

The government collects taxes, $T_{t}$, raises government domestic bonds, $B_{t}$, and has access to a fraction $\nu$ of the oil revenue $\Theta_{t}$, a fraction $\rho_{g}$ of the national development fund $F_{t}$, and its return on international investment of the oil fund at interest rate $R_{t}^{* 1}$. On the other side, the government spends $G_{t}$, remunarates bond holdings at $R^{B}$, distributes transfers $\Gamma_{t}$. The government budget constraint is

$$
T_{t}+B_{t+1}+\nu \Theta_{t}+\left(\rho_{g}+R^{*}\right) F_{t-1}=G_{t}+R_{t}^{B} B_{t}+\Gamma_{t}
$$

The government has the following rules for transfer and public spending:

$$
\begin{aligned}
T_{t} & =\tau_{d}\left(R_{t}^{D}-1\right) D_{t}+\tau_{c} C_{t}+\tau_{w} W_{t} N_{t}+\tau_{k} \mathbb{P} \\
\Gamma_{t} & =\rho_{\Gamma} \nu \Theta_{t} \\
G_{t}^{c} & =\bar{G}^{c} \\
G_{t}^{p} & =K_{t}^{G}-\left(1-\sigma_{G}\right) K_{t-1}^{G}=\bar{G}^{p} \\
G_{t} & =G_{t}^{c}+G_{t}^{p}
\end{aligned}
$$

$\tau_{d}, \tau_{c}, \tau_{w}, \tau_{k}$ are tax rates on return on deposits, consumption, wage and profits, respectively. The government sets the transfer according to the oil revenue by parameter $\rho_{\Gamma} . G_{t}^{c}$ is government current expenditure, which is assumed to be constant and $G_{t}^{p}$ is the government investment in building public capital. $G_{t}$ is the total government expenditure.

\footnotetext{
${ }^{1}$ The best way to introduce $R_{t}^{*}$ is by using the interest rate parity equation. However, for simplicity, we assume that the international interest rate is a markdown of the domestic policy rate.
} 


\subsection{Central Bank and national development fund}

The central bank is a nonprofit institution. Every period, the central bank sets the policy rate by the Taylor rule as follows:

$$
r_{t}^{C B}=\rho_{c b} r_{t-1}^{C B}+\left(1-\rho_{c b}\right)\left(\bar{r}^{C B}+\rho_{\pi}\left(\Pi_{t}-\bar{\Pi}\right)+\rho_{y}\left(Y_{t}-\bar{Y}\right)\right)
$$

where $Y$ is GDP and $1+r_{t}^{C B}=R_{t}^{C B}$. We assume that the central bank uses resources in the national development fund to intervene in financial markets. The national development fund dynamic evolves such that:

$$
F_{t}=\left(1-\rho_{g}\right) F_{t-1}+(1-\nu) \Theta_{t}+R_{t-1}^{C B} B_{t-1}^{C B}-B_{t}^{C B}
$$

which is a result of the national development fund operation with the lending banks, receiving a share of oil revenues and a depreciation of the stock which can be due to many reasons.

\subsection{Market clearing}

By adding all budget constraints, market clearing conditions are:

$$
\begin{aligned}
& G D P_{t}+R_{t}^{*} F_{t-1}=C_{t}+\Phi\left(\frac{i_{t}}{i_{t-1}}\right) i_{t}+\alpha^{o} P_{t}^{o} Y_{t}^{o}+G_{t}+\left(F_{t}-F_{t-1}\right) \\
& N_{t}=N_{t}^{o}+N_{t}^{n} \\
& \mathbb{P}=\Pi_{t}^{K}+\Pi_{t}^{R}+\Pi_{t}^{D}+\Pi_{t}^{L}
\end{aligned}
$$

where $G D P_{t}=Y_{t}^{H}+P_{t}^{o} Y_{t}^{o}$. In equation 45, total output plus the return on foreign investments are equal to consumption, capital investments, government expenditure and net deposits in the national development funds. 


\section{Results}

The model in this paper remains an attempt in integrating a heterogenous banking sector in a newkeynesian framework of an oil economy with a national development fund. It is a general model and is not built for any specific oil-exporting country. Also, it abstracts from the exchange rate, an external sector, frictions in the labor market and so on for the sake of focusing on the role of the financial sector in an oil economy. Here, the model is calibrated to quarterly data for Iran's economy from 1985-2015. Although the model does not capture all the charateristics of the Iranian economy, the results do not alter when the calibration is based on other oil economies.

Table 1 presents the value of the parameters, which are chosen from Iran's data based on the quarterly targets. In summary, a subset of parameters is taken from the literature or is calibrated to match the long-run averages observed in the data in table 2. The source of data is from the World Bank, the Central Bank of Iran and the budget law.

This section discusses the main results of the paper. First, we look at the technology shocks on non-oil firms and on the oil sector and compare the impulse response functions to these shocks with well-established results in papers such as Christiano et al. (2010) and Smets and Wouters (2003). Then, upon the model's success in reproducing similar response for main fundamentals of the economy, we look into the oil price shock on $P^{o}$. Following Pieschacón (2012), we assume that the oil price and technology shocks are stationary and follow an AR(1) process as in (28):

$$
\begin{aligned}
P_{t}^{o} & =\left(1-\rho_{o}\right) \bar{P}^{o}+\rho_{o} P_{t-1}^{o}+\epsilon_{t}^{o} \\
\log \left(A_{t}\right) & =\rho_{i} \log \left(A_{t-1}\right)+\epsilon_{t}^{a}
\end{aligned}
$$

where $\epsilon^{i} \approx N\left(0, \sigma_{i}^{2}\right) \quad i=P^{o}, A$.

\subsection{Technology Shocks}

Figure 7 and 8 show the impulse responses for the aggregate variables coming from the same set of models illustrated previously for a one-standard-deviation shock to the TFP level. A positive 
technology shock increases non-oil output, leading to an improvement in wages and the labor employed in the economy. With perfect labor mobility across sectors, and assuming no change in the oil price, the higher wage demand decreases the labor supply in the oil industry, leading to a decline in oil production and revenues. For this purpose, labor initially increases but then declines as the income effect from the oil sector starts to dominate the substitution effect from the non-oil sector. Due to higher wages and labor, transfers diminish for a few periods as the government receives lower oil revenues and households get wealthier. Following the productivity shock, the marginal cost falls on impact leading to a decline in inflation. The monetary policy follows the inflation path and with a decline in the central bank policy rate all market rates fall. The decline in rates reduces the net worth of the banking system accompanied by deposit and government bond supply. The only exception among the market rates is the return on capital which according to equation (12) follows the productivity shock. Moreover, a positive technology shock decreases firm's capital stock building and equivalently the loan demand.

Figure 7 compares the benchmark model with other scenarios including no price stickiness $\left(\alpha_{p}=0\right)$ and higher cost of capital replacement in the oil sector $\left(\alpha_{o}=0.1\right)$. In 8 , the benchmark model is compared with models without Rotemberg adjustment cost in the deposit bank $\left(\kappa_{D}=0\right)$, no market power for deposit banks $\left(\varepsilon_{D}=\infty\right)$ and finally with near perfect pass-through of rates through lending banks $\left(\eta_{D}, \eta_{B}, \eta_{L} \simeq 0\right)$.

Higher cost of capital replacement in the oil sector only slightly dampens the technology shock impact on the economy. However, the absence of price stickiness affects the monetary policy behavior following an increase in inflation, since retailers can adjust their prices instantly. The absence of sticky rates and imperfectly competitive financial intermediation alter the picture only marginally. Nonetheless a quasi-perfect pass-through of rates through lending banks amplify the contribution to the expansion following a technology shock. The usual drop in inflation induces a policy rate cut, but without interest rate adjustment costs for lending banks, rates fall and converge to the steady state slowly against other scenarios in which the policy rate overshoots after five quarters. Nevertheless, an important difference is that the deposit rate and the interbank rate are still determined by deposit banks with monopolistic power. 
A 1 percent technological shock on the oil industry has generally the same directional impact on the economy, but its impact remains more unattenuated as illustrated in figure 9. This shock increases oil revenues, and improves transfers as the government's receipt from oil enlarges and household consumption expands. The overall labor drops marginally in spite of higher hiring by the oil industry because households become wealthier and choose to work less. Nevertheless, labor in the oil sector constitutes only a small share of total labor, and modest variations in labor or wages cannot have an important impact on the real and financial sector. As a result, the government oil revenue remains the principal channel through which technological advances in the oil industry propagate into the economy. With higher revenues, government issues less bonds and carries out more public investment, which builds up public capital stock. On the impact, this would reduce the marginal cost and inflation, inducing the monetary policy reaction of reducing the policy rate.

\subsection{Oil Price Shock}

Figure 10 and 11 illustrate the impulse responses for the aggregate variables after a one-standarddeviation shock to the oil price. A positive oil price shock boosts oil revenue, affecting the economy through different channels. First, due to the enhanced oil revenues, investment in the oil industry strengthens and boosts the capital stock in the sector, which further amplifies oil production and total output. Second, the rising oil revenue induces an increase in labor. This is interpreted for the non-oil sector as a labor supply shock, which inflates wages. To compensate for the loss, the nonoil sector responds by revising its prices upward. At the same time, the monetary policy reacts to the positive output gap and higher prices by increasing the policy rate momentarily. Nevertheless, the detrimental impact of higher oil prices on the non-oil sector pushes total labor below its steady state value, resulting in falling wages and prices, reversing the very short-term impact of higher oil prices. This shows the importance of structure within an economy and how the oil and non-oil sectors are linked. This development happened in our model, because the two sectors compete over labor. This effect could be strengthened, if the capital in the oil sector were of the same material as in the non-oil sector. Inversely, higher oil prices can have a positive impact on the non-oil sector, if for instance, government subsidies to firms were important, or government would use more of 
non-oil sector products in its public investment program.

As prices start to fall and the central bank cuts the policy rate, other rates start to decline. Following the drop in rates, deposit and bond supply plummet, partly because households move to smooth their consumption and the government receives higher revenues from oil. Naturally, with rising oil revenues, the government finances its expenses directly from oil revenues, leading to a shift from a modern state to an economy with reduced dependence on bonds and even taxes.

Also, due to lower wages and a richer government, households choose to work less and receive more state transfers and therefore total consumptions grow. In the medium-term, non-oil firms will substitute lower labor with the capital accumulation by taking advantage of lower market rates for borrowing. For this reason, capital stock rises after the fall in interest rates and labor. The oil fund originally overshoots thanks to higher oil revenues, but because of lower deposits in the system and higher loan demand coming from non-oil firms, the oil fund must inject resources to the banking system. Eventually, resources go below the steady state. The oil fund resource injection is complemented by the central bank's lending to banks. Indeed, due to higher deposits at the beginning and lower bond supply, banks do not use the central bank's lending facilities. As soon as non-oil firms start to invest and their loan demand increases, central bank lending goes back to the steady state. Indeed, the central bank's rate, following the Taylor rule, rises at first based on output and inflation gaps. However, due to rigidities in adjusting the interbank rate, the increase in the interbank rate is smaller than that of the central bank. As a result, the lending bank has more incentive to borrow in the interbank market rather than directly from the central bank.

In this setup, the wage is determined only by non-oil firms. Although higher oil price makes it more efficient to reallocate resources from non-oil to the oil sector, this wage rigidity prevents a perfect substitution in the general equilibrium. The transmission mechanism could be reinforced if wage dispersion existed in the model and the wage was determined in a competitive labor market or even in monopolistic model à la Calvo for instance.

In addition to the benchmark model, figure 10 shows the oil shock under two alternative scenarios with no Calvo pricing and higher oil re-investment. The two models behave similarly to the benchmark model; however, they illustrate the role of each component in the propagation of 
shocks. With $\alpha_{p}=0$ and no price stickiness, retailers can adjust the prices instantly, which dampens the impact of the shock on almost all variables. Since prices adjust immediately, the mechanism that happens with the full model at the beginning of the shock disappears. As in the benchmark model, with positive oil price shock the oil industry absorbs more labor. The non-oil sector responds to the shock by increasing salaries and prices. However, this time retailers respond to the monetary policy reaction of a rate increase immediately, and, therefore, prices fall on impact. The non-oil sector's output falls as a result of losing labor and the inability to increase prices. With a shrinking labor force and cheaper capital acquirement, non-oil firms start accumulating capital. Households choose to work less, since the salaries have not increased and because transfers increase due to higher oil price. Nonetheless, consumption and transfers are weaker than in the benchmark model and the government initially issues higher bonds to support transfers and public investment.

The case of higher investment in the oil sector is more interesting. The response is very similar to the benchmark model; however, GDP and consumption expand more, and convergence to the steady state is slower. The reason is that as the oil output upsurges with the sector's investment intensification, production and labor demand also increase. The impact on the non-oil sector is as detrimental as in the benchmark, with a more protracted effect. The oil sector is greedier on labor, and the non-oil output declines faster while trying to compensate for labor losses with higher investment. This process is facilitated by suppressed market rates. Because of the prolonged impact on non-oil firms, the monetary reaction remains protracted, and rates remain low for a longer period.

\subsection{Application}

Once the model has been calibrated and its propagation mechanisms studied, we can use it to analyze the role of the financial sector and banks, raised in the introduction. We are not looking at the shocks originating within the banking sector, although they can be interesting, but are simply studying the role of banks in propagating an oil shock to the rest of the economy. Because agents are not credit constraint, a conventional financial accelerator mechanism is absent in the model. 
The goal of the model, therefore, is not to replicate a financial accelerator model, because by construction it amplifies the impact of shocks. The goal of adding a financial sector was to 1) introduce a national development fund and link it to the banking sector and the government; 2) to see the impact of an interbank market on shocks; and 3) to introduce different rates in the economy and later on intervention and exchange rate stability mandate for the central bank.

Figure 11 demonstrates the response function to the oil shock with different financial system component changes. We look at the responses with changes on the deposit bank where the deposit rate adjustment cost has been removed, $\kappa_{D}=0$, and the case with no monopolization power for deposit banks, i.e. $\varepsilon_{D}=$ inf. Then we analyze the impact of instantaneous rate changes at lending banks by removing all adjustment costs, i.e. $\eta_{B, D, L}=0$.

The monopolization of the deposit bank or the deposit rate adjustment cost appear to have a mild impact on the model. In contrast, the response functions related to lending banks with no adjustment costs have a significant impact. Indeed, with instantaneous rate adjustments, non-oil firms replace the labor with capital. Therefore, the overall demand for labor falls at the beginning and investment soars. This process occurs at the same time as the central bank rate cut because this time firms do not see the necessity of increasing their price levels for paying higher salaries. Instead, the overall price index falls, and the central bank responds by cutting the policy rate, which in turn boosts investment. However, after two quarters, the non-oil output increases to the point that firms require hiring and therefore labor overshoots. Since labor declines right after the shock, consumption declines, but it increases as transfer and labor start to rise and the overall level remains higher than the benchmark and other scenarios. Government bond supplies also decline on account of lower bond rates and higher government revenues from oil. The major difference in this scenario is the positive spillover from the oil to the non-oil sector, because of the firms' labor-choosing behavior, falling prices, and the monetary policy reaction. As a result, the cumulative impact on GDP stands higher than in other scenarios. Nevertheless, this result remains very sensitive to the parameters' calibration. With different parameters for the households' utility function for labor and leisure and modified Taylor rule, the results could be different and potentially closer to the benchmark model. 


\section{Concluding remarks}

This paper studies an oil economy in a New-Keynesian framework with a heterogenous banking sector. The main purpose is to analyze how different components of an oil economy from the oil sector, public financing from oil resources, and national development fund interact together and with a banking sector in propagating shocks in the economy.

Several results are provided. First, because of complementarities between the oil and non-oil sectors, the labor market becomes an important source of shocks spillover in this economy. This is seen especially in the oil sector technology shock and oil price shock. The main reason here is the fixed labor supply. In an economy with slack capacity of labor, the results can be different somewhat and a positive technology shock or oil price shock would have larger impact on GDP and consumption. Therefore, policies aimed at stabilizing wages and prices prevents these variables to play their role of automatic stabilizers to avoid large swings of production factors between sectors. The detrimental effect on the non-oil sector also results in a pro-cyclical behavior of the monetary policy to support price stability and stimulate the non-oil sector. Nevertheless, this setup can compensate for the lack of an exchange rate in the model to capture a similar Dutch disease kind of phenomena in oil economies.

Second, the government's role in propagating shocks is essential. When the oil revenues increase due to higher oil prices or a positive technological shock, the government magnifies the transfer to households and increases public capital expenditure. Higher transfer indeed improves consumption, but it also affects the households' decision of labor allocation. On the other hand, since public capital is used in the non-oil output, total output should increase proportionally, which would result in a higher fiscal multiplier.

Third, although banks do not play a key role in the propagation of oil shocks in this model, they have a critical role in amplifying them. Because the oil sector is not directly exposed to the banking sector, and non-oil firms are neither credit constrained nor is a default allowed in the model, banks are not essentially driving the responses to the oil sector shocks. Instead banks in this model can differentiate between market rates. Various frictions in the banking sector affects the impulse response functions. But the deposit bank monopolistic power or deposit rate adjustment 
cost have insignificant impact compared to adjustment costs in lending banks. This is due to the fact, that lending banks are linked to the government, non-oil firms, national development fund and the central bank.

This model provides plausible explanations in a stylized manner that can help improve our understanding of how different sectors of an oil economy interact, but naturally it comes with many limitations. As mentioned before, the model remains very sensitive to the labor market. In reality, the oil sector is capital intensive. Additionally, the labor force is very specialized, and the degree of substitutability remain low. Furthermore, the model abstracts from the exchange rate and trade. Indeed, in oil economies the major export remains oil, and the revenue is accrued to the government and a sovereign wealth fund or a development fund. The negative spillover effect from the oil to the non-oil sector can be exacerbated by modeling a small open economy and introducing a real exchange rate. Moreover, by choosing credit-constrained firms and introducing collaterals, the banking system becomes part of the propagation mechanism, and the financial accelerator must function. Finally, the central banks of many oil-exporting countries have the implicit mandate of exchange rate stabilization. The model dynamic can be improved by choosing exchange rate stabilization as one of the objectives of the central bank. For this purpose, we have to introduce an intervention rule as well. 


\section{References}

Arezki, R. and Ismail, K. (2013). Boom-bust cycle, asymmetrical fiscal response and the Dutch disease. Journal of Development Economics, 101:256 - 267. 3

Arouri, M. E. H., Lahiani, A., and Bellalah, M. (2010). Oil Price Shocks and Stock Market Returns in Oil-Exporting Countries: The Case of GCC Countries. International Journal of Economics and Finance, 2:132-139. 4

Berg, A., Portillo, R., Yang, S.-C. S., and Zanna, L.-F. (2013). Public investment in resourceabundant developing countries. IMF Economic Review, 61(1):92-129. 8, 28

Bhattacharjee, A., Thoenissen, C., et al. (2007). Money and monetary policy in dsge models. In Money Macro and Finance (MMF) Research Group Conference 2006, number 78. Citeseer. 28

Chemingui, M. A. and Roe, T. (2008). Petroleum revenues in Gulf Cooperation Council, countries and their labor market paradox. Journal of Policy Modeling, 30(3):491-503. 3

Choudhary, M. A. and Limodio, N. (2017). Deposit Volatility, Liquidity and Long-Term Investment: Evidence from a Natural Experiment in Pakistan. Technical report. 4

Christiano, L., Rostagno, M., and Motto, R. (2010). Financial factors in economic fluctuations. Working Paper Series 1192, European Central Bank. 10, 17

Christiano, L. J., Eichenbaum, M., and Evans, C. L. (2005). Nominal rigidities and the dynamic effects of a shock to monetary policy. Journal of political Economy, 113(1):1-45. 6

Daliri, H. and Mehrgan, N. (2015). The anatomy of dsge models with banking industry for iran's economy. Iranian Journal of Economic Studies, 4(2):17-49. 28

Dib, A. (2010). Capital Requirement and Financial Frictions in Banking: Macroeconomic Implications. Technical report. 12

Erbil, N. (2011). Is Fiscal Policy Procyclical in Developing Oil-Producing Countries? IMF Working Papers 11/171, International Monetary Fund. 2 
Fayyad, A. and Daly, K. (2011). The impact of oil price shocks on stock market returns: Comparing GCC countries with the UK and USA. Emerging Markets Review, 12(1):61-78. 4

Fernández-Villaverde, J. and Rubio-Ramírez, J. F. (2009). A baseline dsge model. University of Pennsylvania (October). Robert E. Hall, 229. 6, 9

Gerali, A., Neri, S., Sessa, L., and Signoretti, F. M. (2010a). Credit and banking in a DSGE model of the euro area. Temi di discussione (Economic working papers) 740, Bank of Italy, Economic Research and International Relations Area. 6

Gerali, A., Neri, S., Sessa, L., and Signoretti, F. M. (2010b). Credit and banking in a dsge model of the euro area. Journal of Money, Credit and Banking, 42(s1):107-141. 12

Gertler, M. and Karadi, P. (2011). A model of unconventional monetary policy. Journal of monetary Economics, 58(1):17-34. 7, 28

Guerra-Salas, J. (2014). Government investment and the business cycle in oil-exporting countries. Technical report, Mimeo Fordham University. 28

Leeper, E. M., Walker, T. B., and Yang, S.-C. S. (2010). Government investment and fiscal stimulus. Journal of monetary Economics, 57(8):1000-1012. 8

Motevaseli, M., Bahrami, I., Shahmoradi, A., and Komijani, A. (2011). A new keynesian dynamic stochastic general equilibrium (dsge) model for an oil exporting country. 28

Murphy, P. L., Villafuerte, M., and Ossowski, R. (2010). Riding the Roller Coaster; Fiscal Policies of Nonrenewable Resource Exporters in Latin America and the Caribbean. IMF Working Papers 10/251, International Monetary Fund. 2, 3

Pieschacón, A. (2012). The value of fiscal discipline for oil-exporting countries. Journal of Monetary Economics, 59(3):250-268. 3

Pieschacón, A. (2012). The value of fiscal discipline for oil-exporting countries. Journal of Monetary Economics, 59(3):250-268. 17 
Rotemberg, J. J. (1982). Monopolistic price adjustment and aggregate output. The Review of Economic Studies, 49(4):517-531. 13

Smets, F. and Wouters, R. (2003). An Estimated Dynamic Stochastic General Equilibrium Model of the Euro Area. Journal of the European Economic Association, 1(5):1123-1175. 17

Smets, F. and Wouters, R. (2007). Shocks and frictions in us business cycles: A bayesian dsge approach. American economic review, 97(3):586-606. 6

Tazhibayeva, K., Husain, A. M., and Ter-Martirosyan, A. (2008). Fiscal Policy and Economic Cycles in Oil-Exporting Countries. IMF Working Papers 08/253, International Monetary Fund. 3 


\section{Appendix}

Table 1: Calibrated parameters (quarterly)

\begin{tabular}{lccc} 
Parameters & Symbol & Value & source \\
\hline \hline & $\beta$ & 0.9595 & $R^{D}=0.18$ (annually) \\
Discount factors & $\sigma$ & 1.5 & Bhattacharjee et al. (2007) \\
Consumption elasticity & $\chi_{N}$ & 0.52 & $N=1$ \\
Relative utility weight of labor & $\phi$ & 2.17 & Motevaseli et al. (2011) \\
Inverse Frisch elasticity of labor supply & $\gamma_{n}$ & 0.30 & $K / G D P=2$ \\
Elasticity of private capital & $\gamma_{G}$ & 0.1 & Berg et al. (2013) \\
Elasticity of public capital & $\gamma_{o}$ & 0.80 & $K^{o} /$ GDP $=0.30$ \\
Elasticity of private capital in oil & $\theta, \chi, \alpha_{p}$ & $9,0.241,0.50$ & $30 \%$ Mark up,Daliri and Mehrgan (2015) \\
Coef. of intermediate producer & $\delta_{k}, \delta_{o}, \delta_{g}$ & $0.05,0.007,0.1$ & Motevaseli et al. (2011) \\
Depreciation rates & $\xi$ & 2 & Daliri and Mehrgan (2015) \\
Capital Pro. adj. cost & $\varepsilon, \kappa_{D}$ & $237,1.5$ & $R^{I B}=0.20$ (annually) \\
Coef. of deposit bank & $\tau_{c}, \tau_{d}, \tau_{w}, \tau_{k}$ & $0.09,0,0.04,0.15$ & Average tax rates \\
Taxes & $\rho_{c b}, \rho_{\pi}, \rho_{y}$ & $0.10,1.5,0.125$ & Gertler and Karadi (2011) \\
Central bank & $\rho_{o}$ & 0.80 & Guerra-Salas (2014) \\
Oil AR processes & $\rho_{A}, \rho_{A^{o}}, \rho_{\xi}$ & $0.80,0.90,0.90$ & \\
Other AR processes & $\nu$ & 0.70 & \\
Gov. share of oil revenue & $\rho_{g}$ & 0.05 & \\
Gov usage of oil fund & $\rho_{\Gamma}$ & 0.33 & \\
Share of Transfer in Oil Rev. & $\alpha_{o}$ & 0.01 & \\
Share of investment in oil revenue & $\eta_{D}, \eta_{B}, \eta_{L}$ & $2,0.2,2$ & \\
Adj. costs of lending bank & & & \\
& & &
\end{tabular}

Table 2: Steady state of the benchmark model(quarter)

\begin{tabular}{lcc} 
Variable & symbol & Steady State/GDP \\
\hline \hline Consumption & $C$ & 0.64 \\
Transfer & $\Gamma$ & 0.05 \\
Private capital & $K$ & 2 \\
Oil capital & $K^{o}$ & 0.36 \\
Public capital & $K^{G}$ & 0.48 \\
Non-oil output & $P^{H} Y^{H}$ & 0.75 \\
Oil revenue & $P^{o} Y^{o}$ & 0.25 \\
Gov. expenditure & $G_{c}, G_{p}, G$ & $0.25,0.046,0.30$ \\
Investment & $X$ & 0.10 \\
Gov. loans & $B$ & 0.40 \\
Tax & $T$ & 0.09 \\
Total government's budget & & 0.78 \\
Current expenditure/investment & $G_{c} / G_{p}$ & 5.5
\end{tabular}




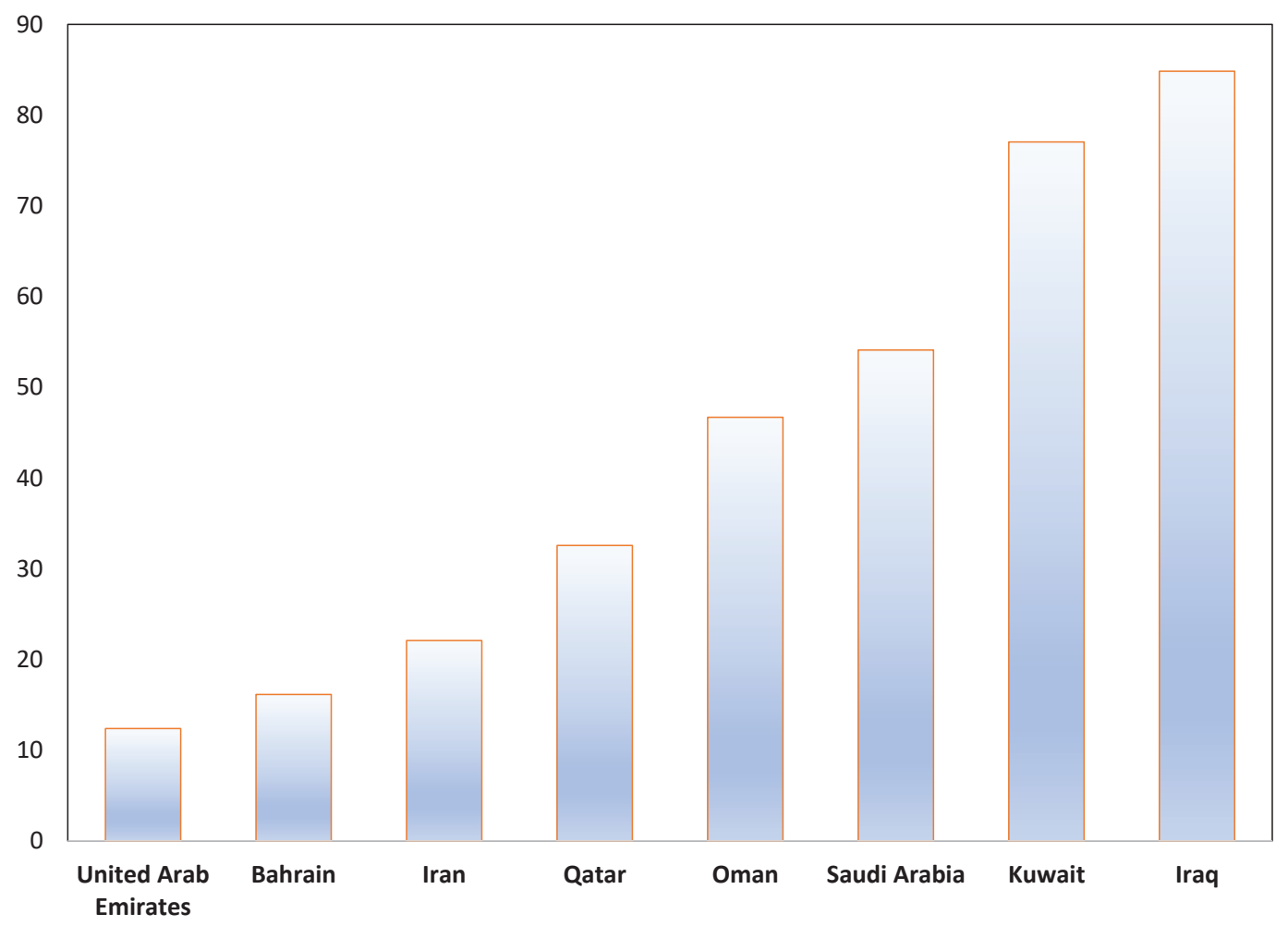

Figure 1: Oil Revenue to export

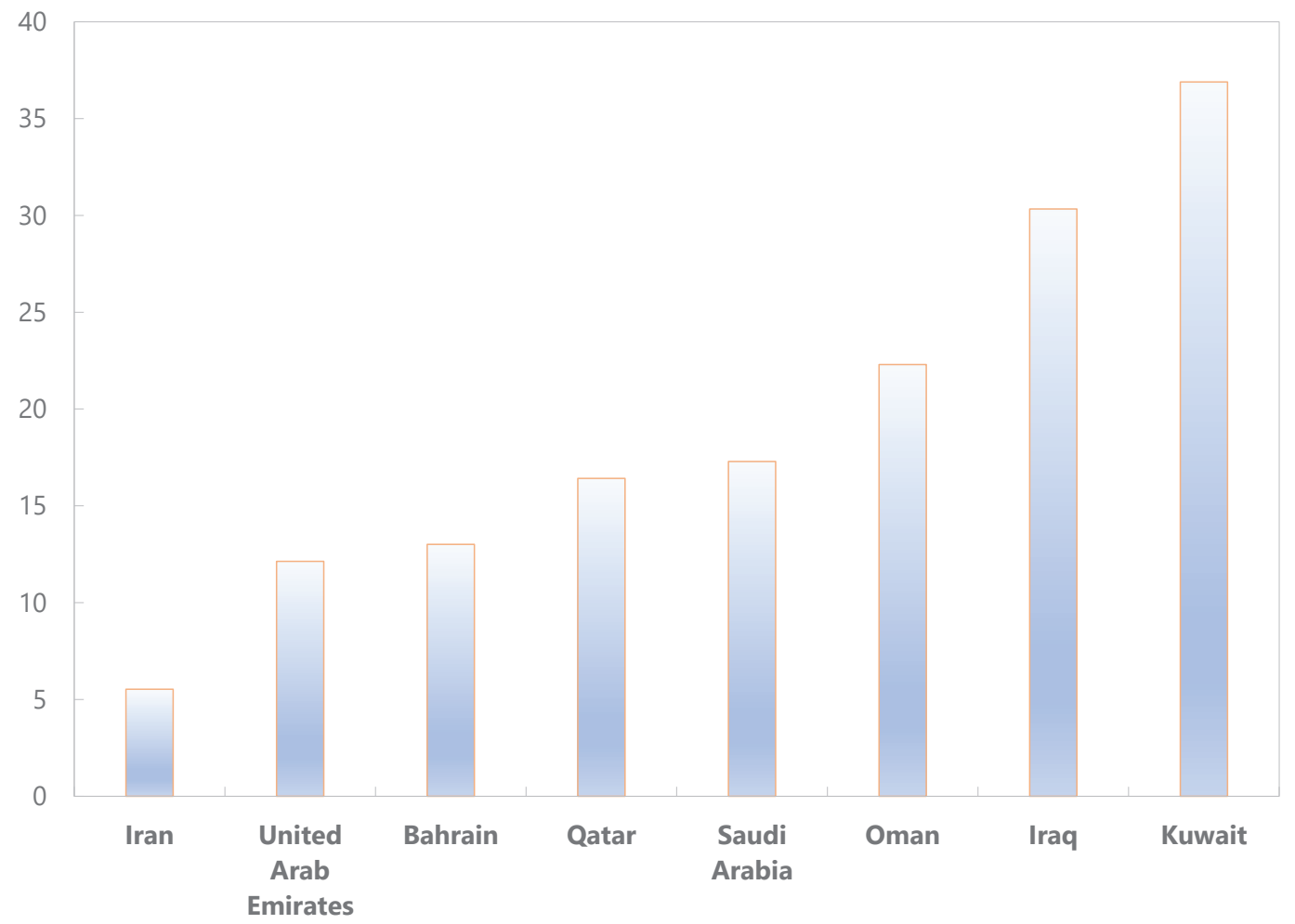

Figure 2: Oil Revenue to GDP 


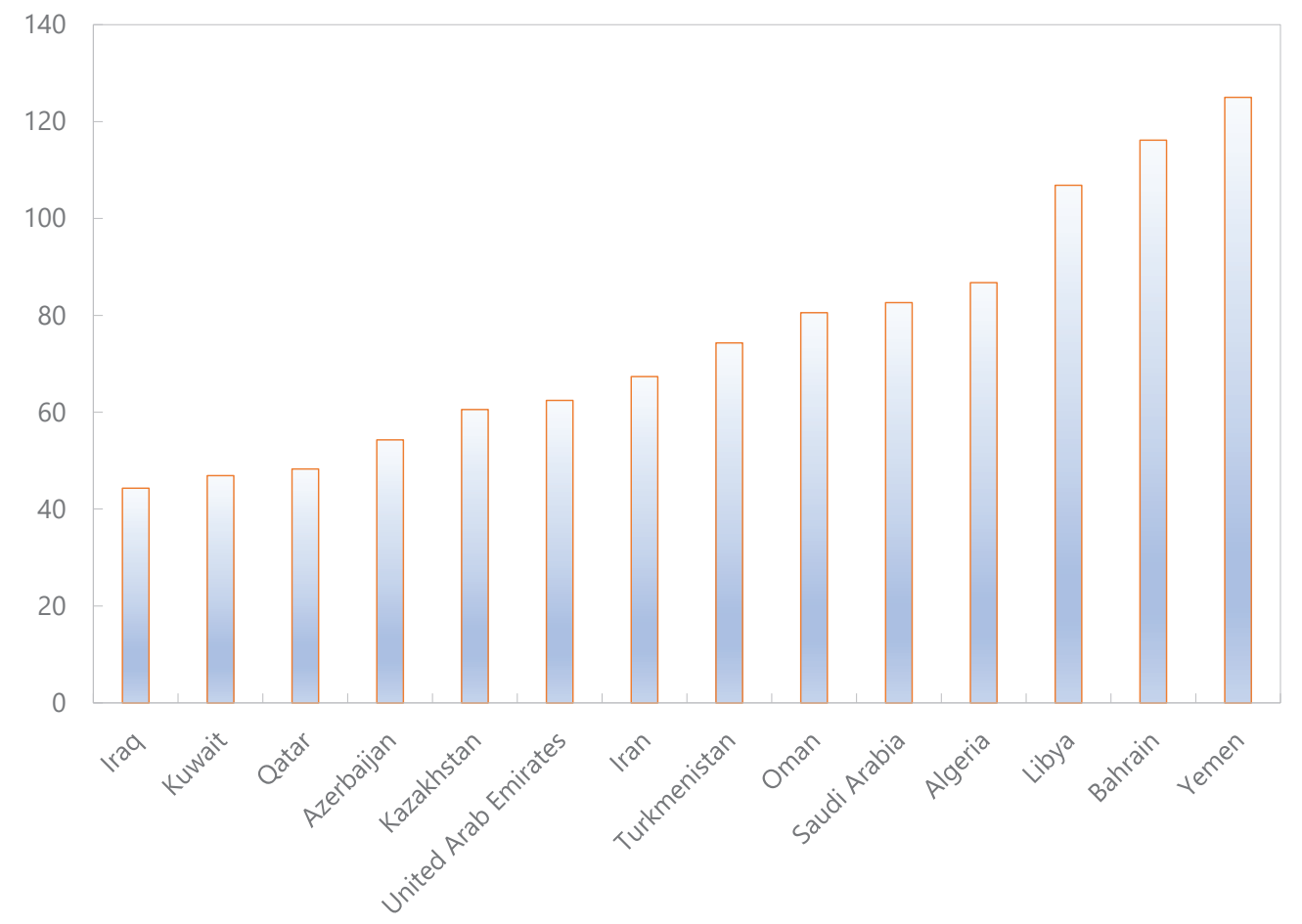

Figure 3: IMF fiscal breakeven price

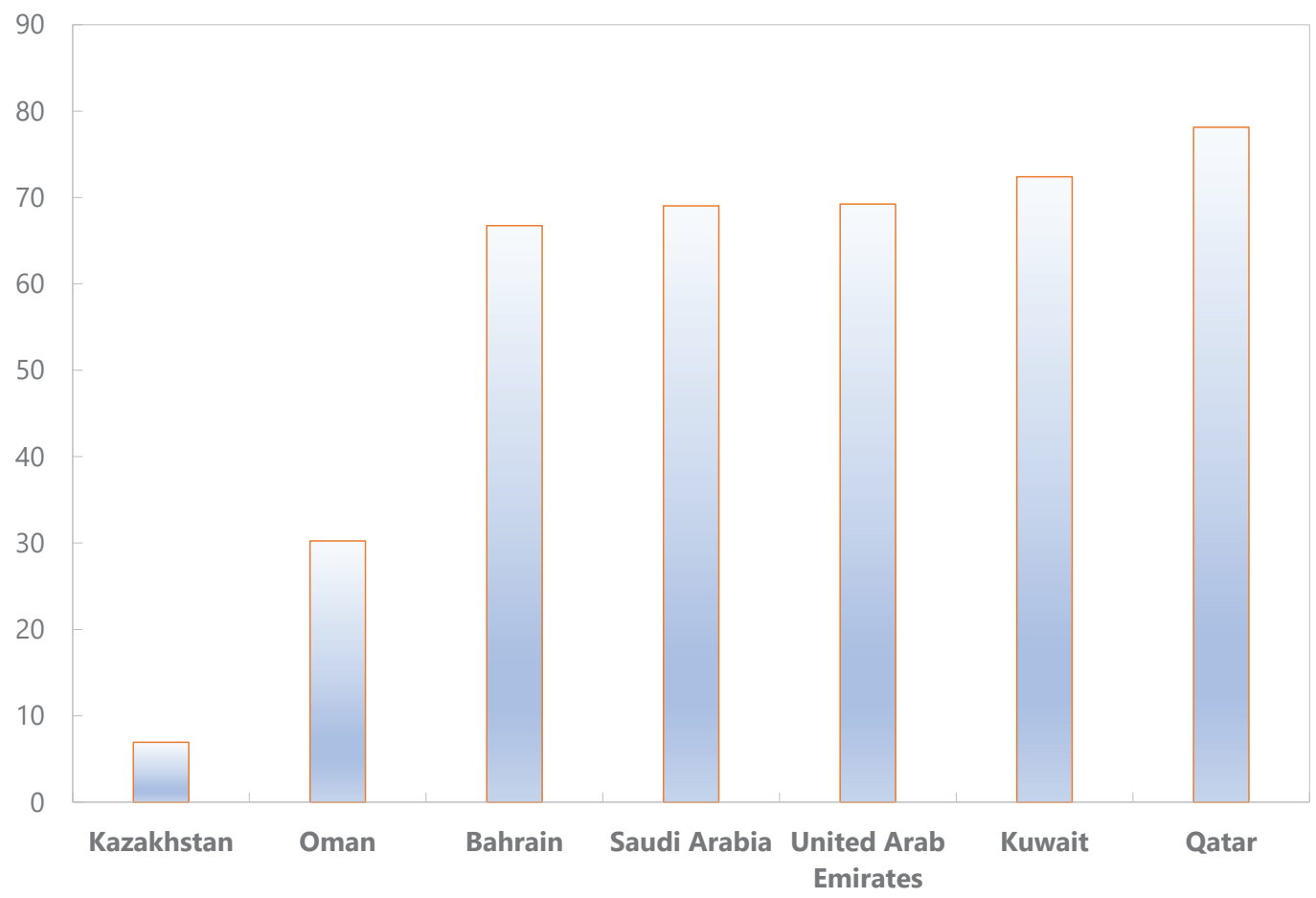

Figure 4: Market capitalization to GDP 


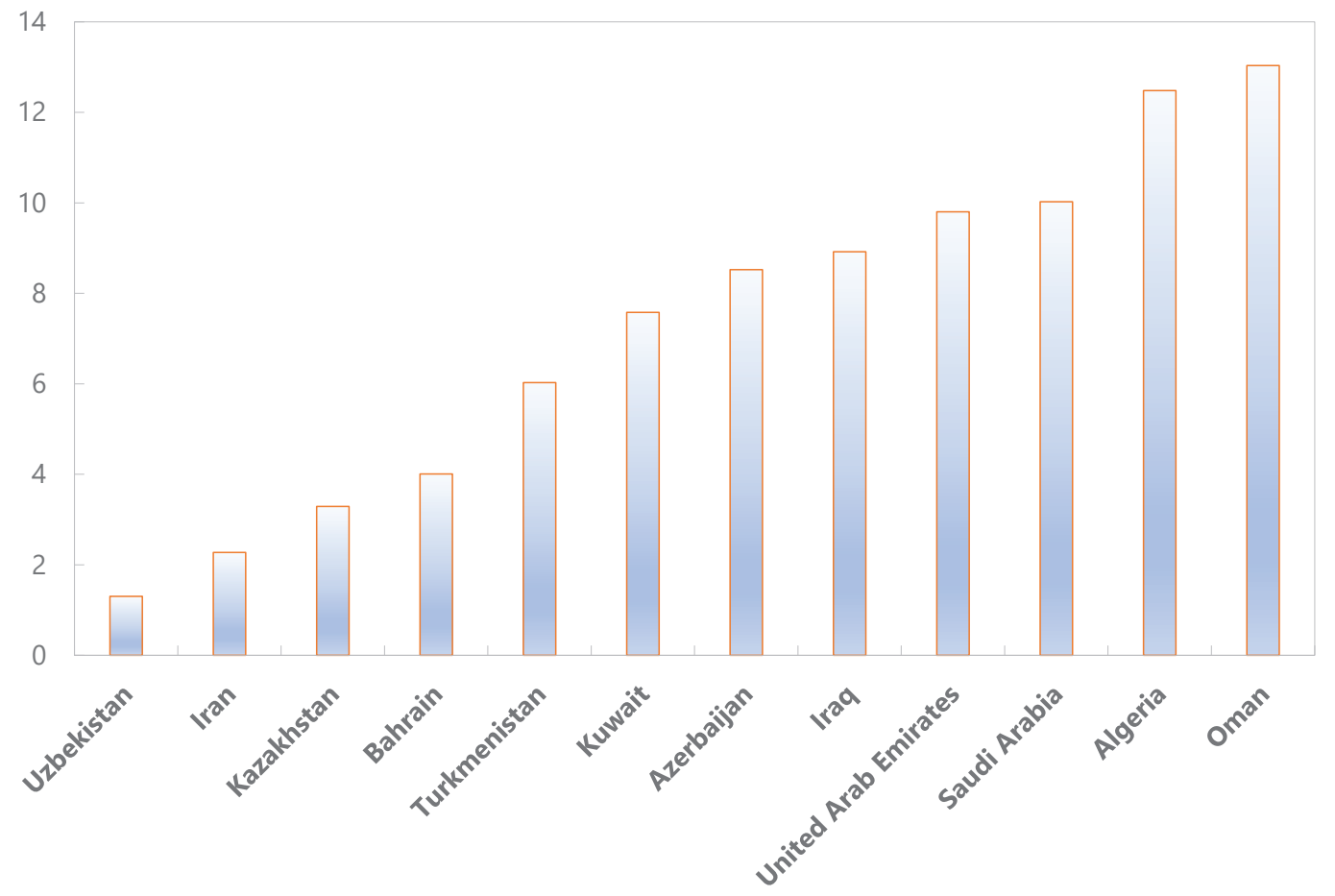

Figure 5: Public investment to GDP

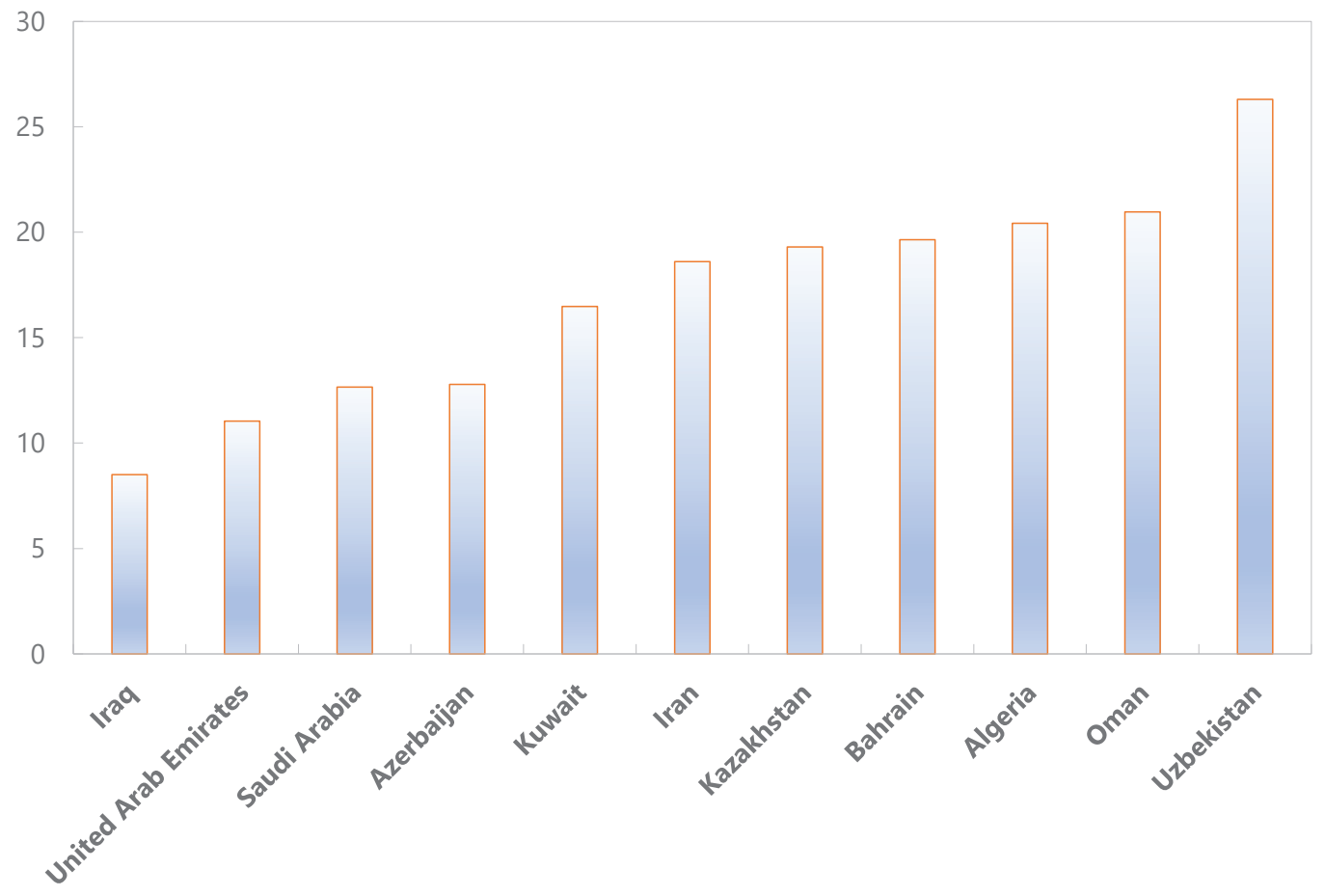

Figure 6: Private investment to GDP 


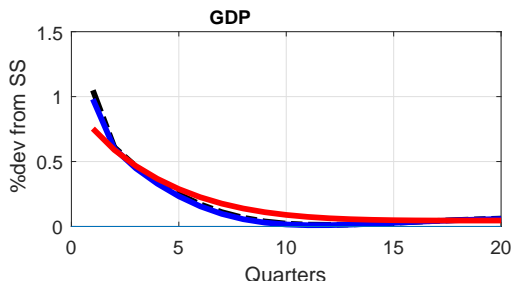

CB Loan to Banks $\left(\mathrm{B}^{\mathrm{CB}}\right)$

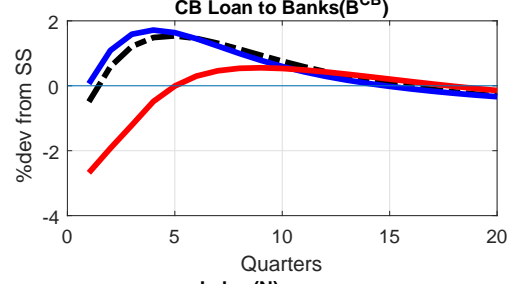

N
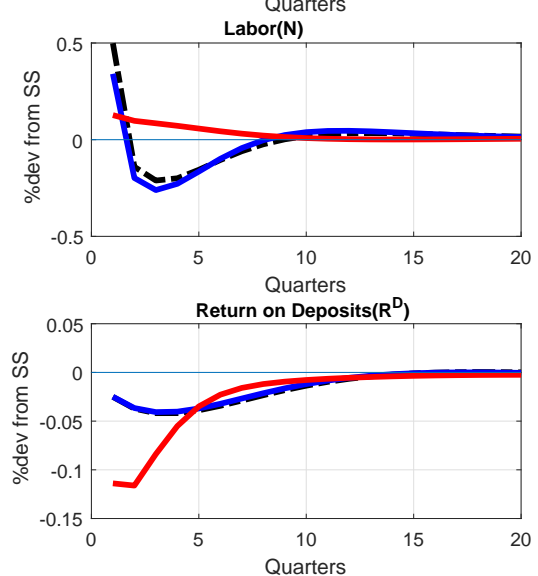
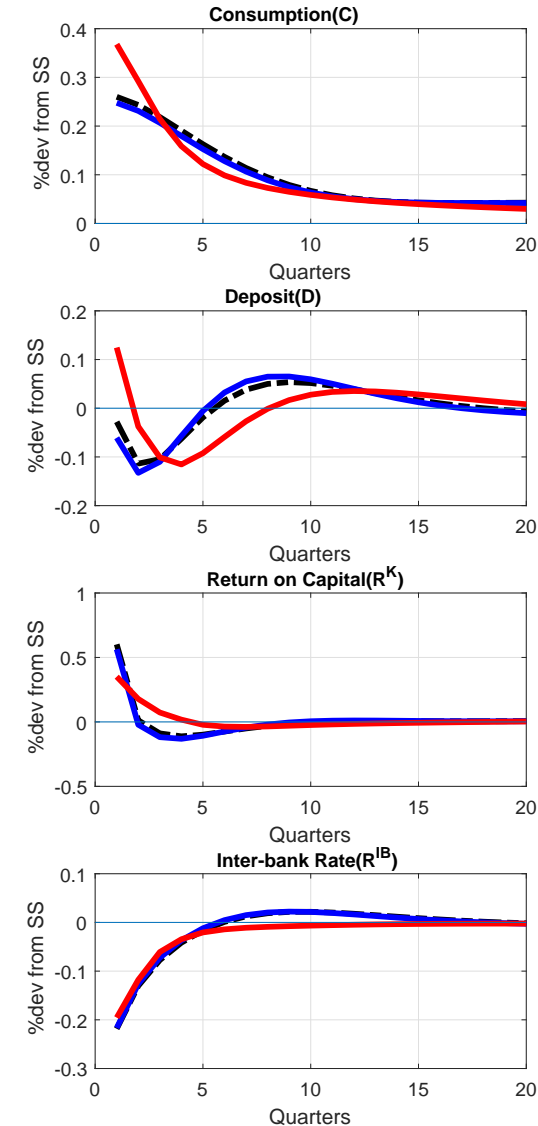
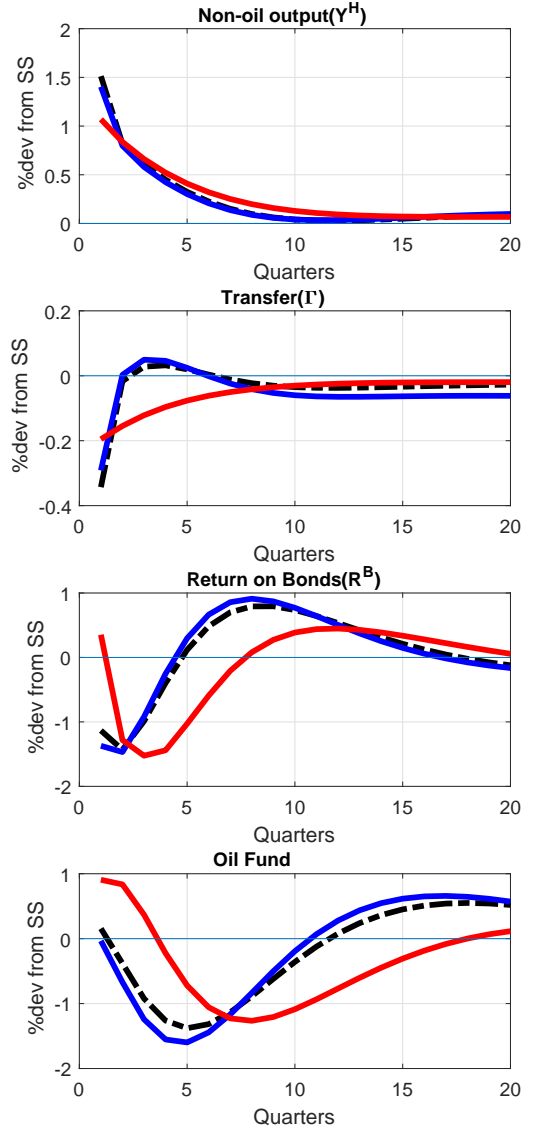
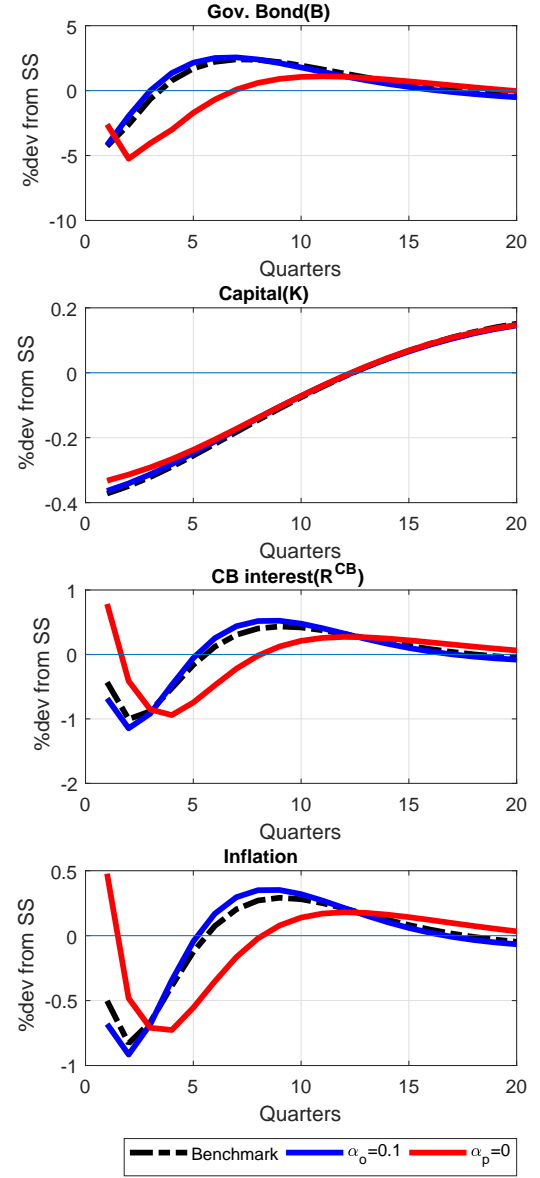

Figure 7: Percentage change from the steady state for the key variables. The shock is a $1 \%$ standard deviation positive technological shock to non-oil firms. Benchmark model is compared to no price stickiness $\left(\alpha_{p}=0\right)$ and higher cost of capital replacement in the oil sector $\left(\alpha_{o}=0.1\right)$ scenarios. 

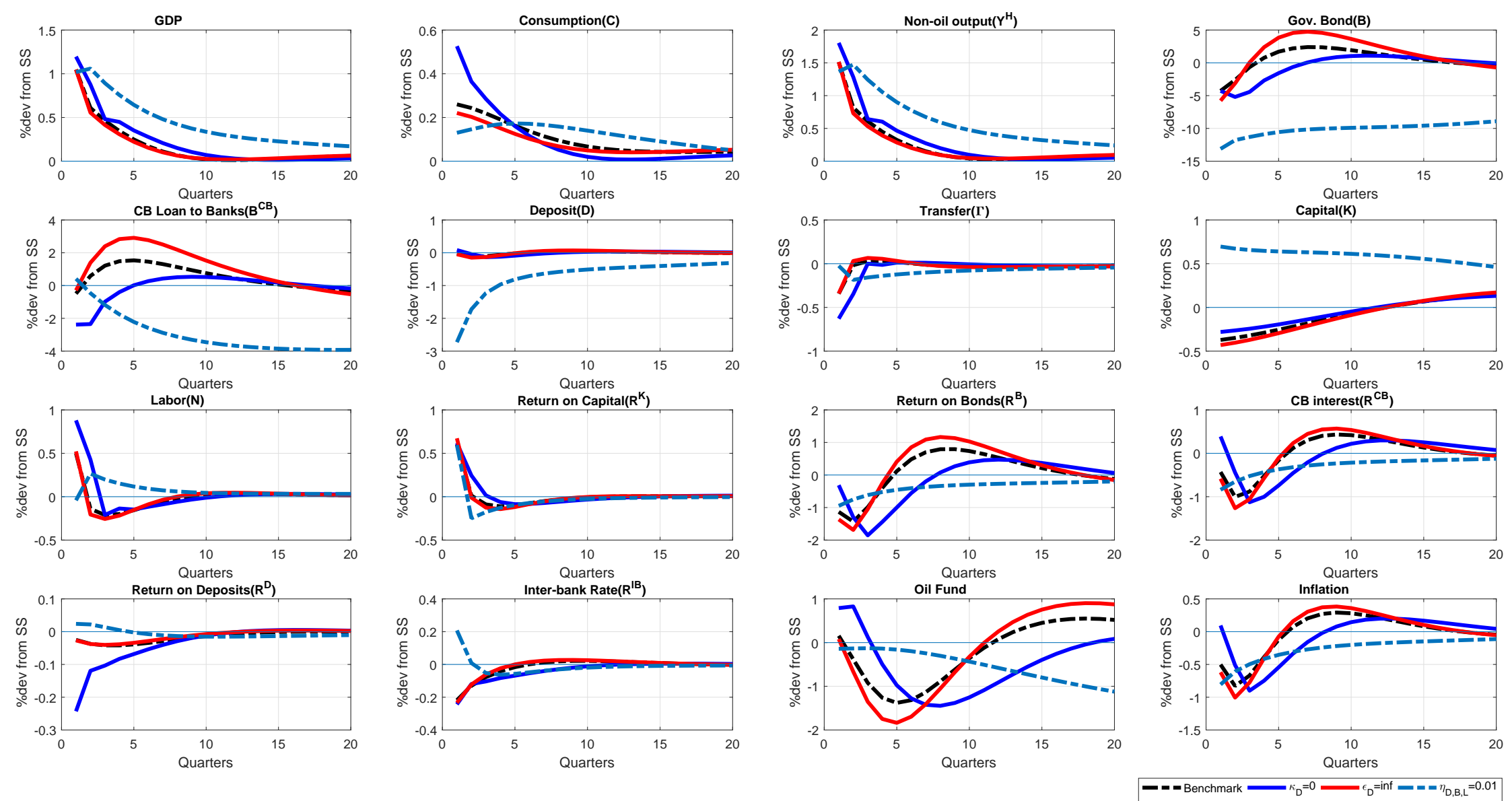

Figure 8: Percentage change from the steady state for the key variables. The shock is a $1 \%$ standard deviation positive technological shock to non-oil firms. The benchmark model is compared with models without Rotemberg adjustment cost in the deposit bank $\left(\kappa_{D}=0\right)$, no market power for deposit banks $\left(\varepsilon_{D}=\infty\right)$ and finally with near perfect pass-through of rates through lending banks $\left(\eta_{D}, \eta_{B}, \eta_{L} \simeq 0\right)$. 

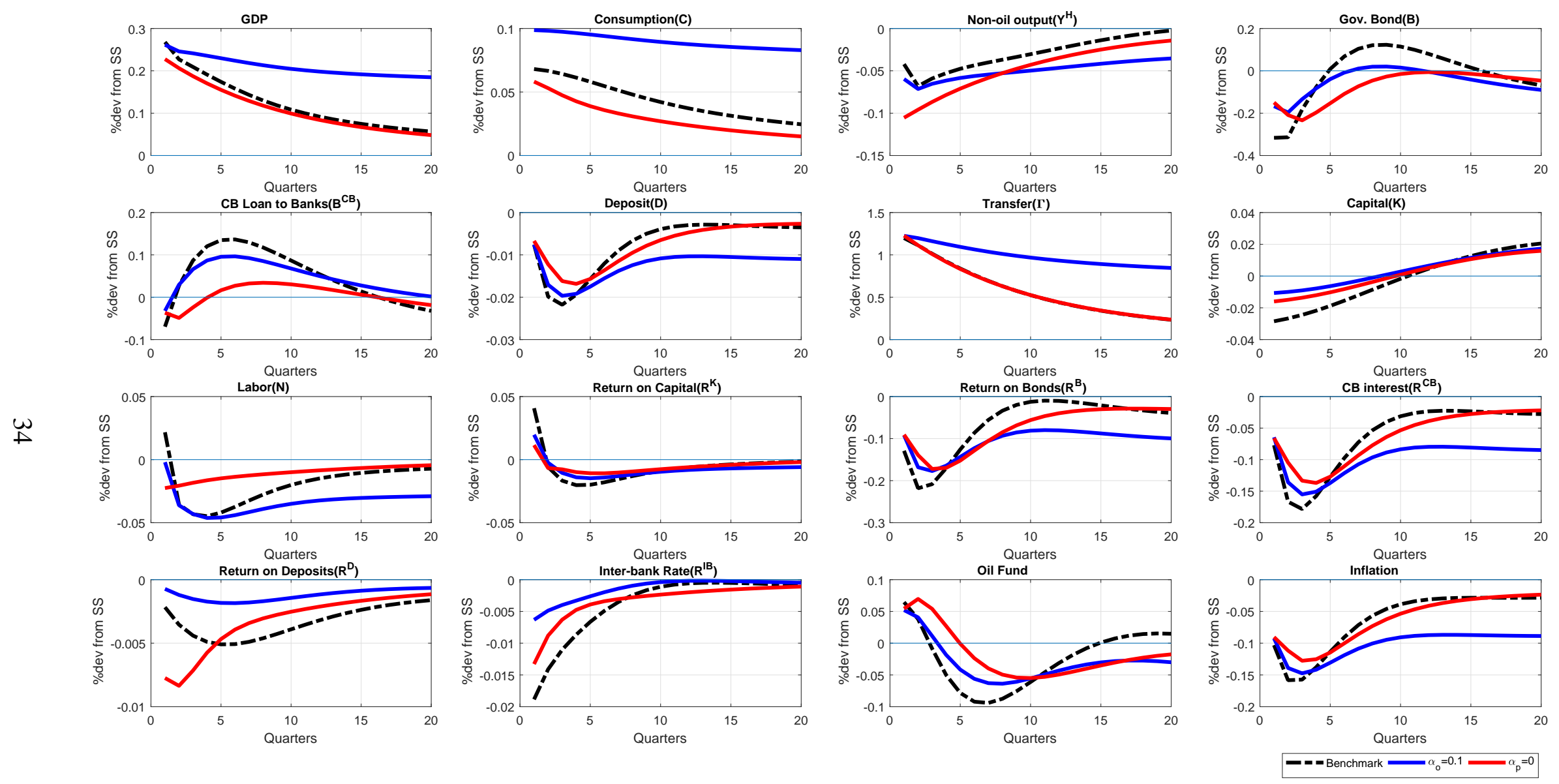

Figure 9: Percentage change from the steady state for the key variables. The shock is a $1 \%$ standard deviation positive technological shock to the oil sector. Benchmark model is compared to no price stickiness $\left(\alpha_{p}=0\right)$ and higher cost of capital replacement in the oil sector $\left(\alpha_{o}=0.1\right)$ scenarios. 

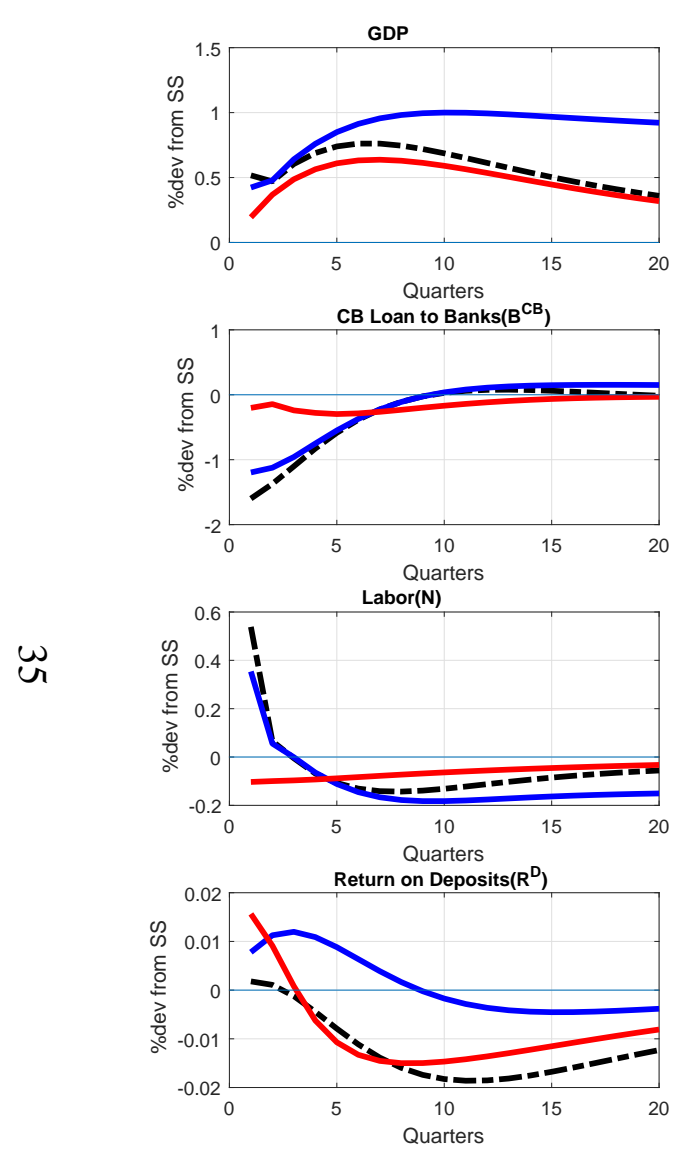
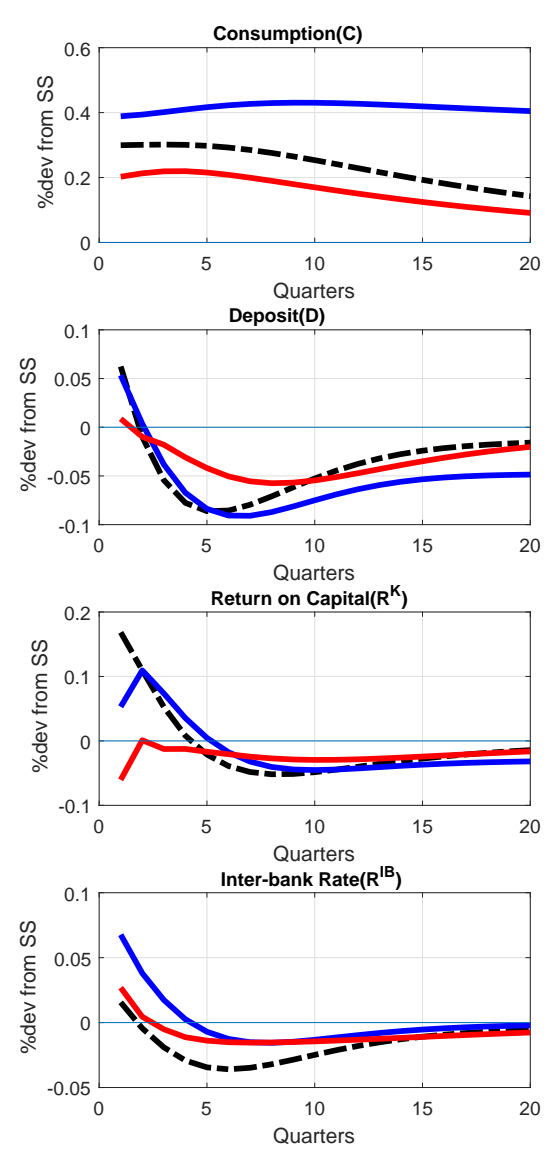
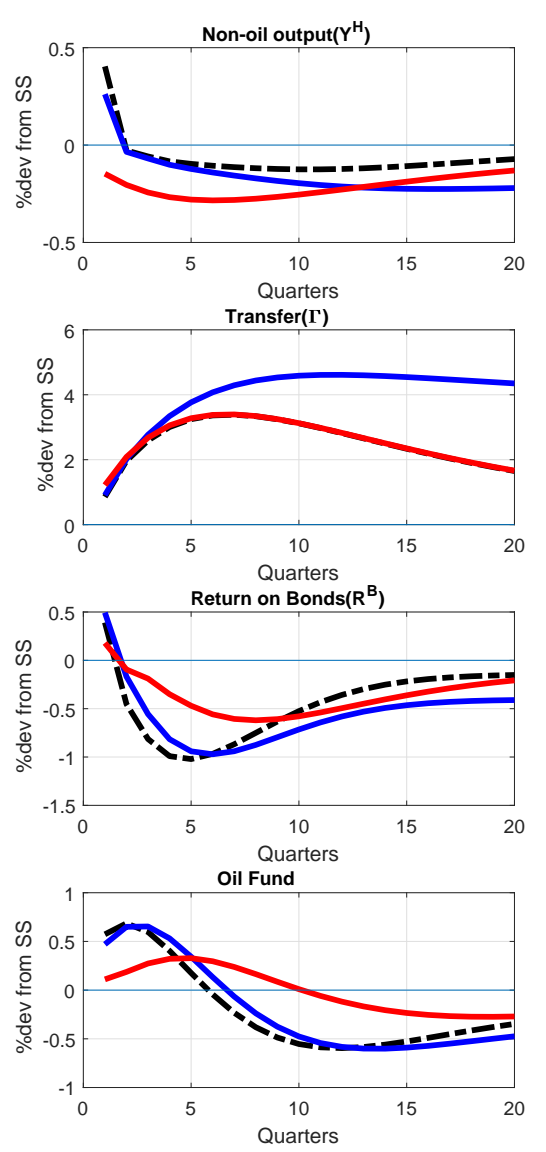
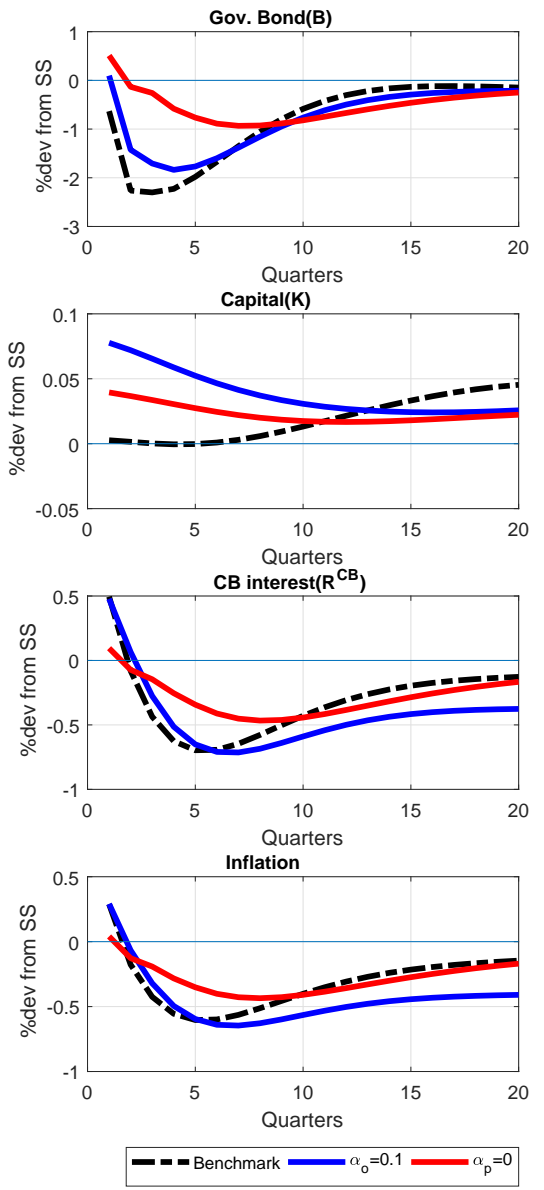

Figure 10: Percentage change from the steady state for the key variables. The shock is a $1 \%$ standard deviation positive technological shock to the oil sector. Benchmark model is compared to no price stickiness $\left(\alpha_{p}=0\right)$ and higher cost of capital replacement in the oil sector $\left(\alpha_{o}=0.1\right)$ scenarios. 

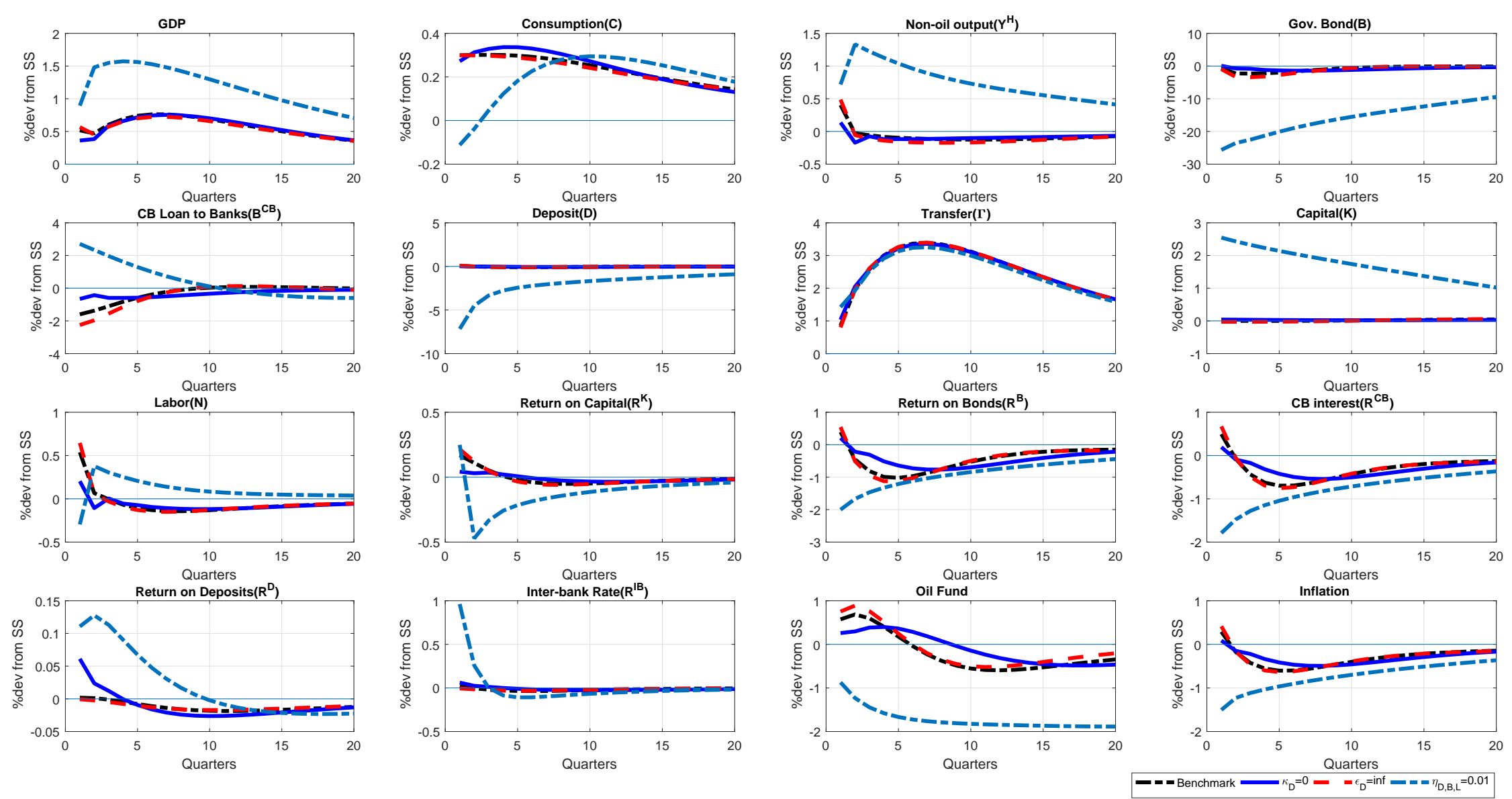

Figure 11: Percentage change from the steady state for the key variables. The shock is a $1 \%$ standard deviation positive shock to the oil price. The benchmark model is compared with models without Rotemberg adjustment cost in the deposit bank $\left(\kappa_{D}=0\right)$, no market power for deposit banks $\left(\varepsilon_{D}=\infty\right)$ and finally with near perfect pass-through of rates through lending banks $\left(\eta_{D}, \eta_{B}, \eta_{L} \simeq 0\right)$. 